Portland State University

PDXScholar

1979

\title{
The First Years of Life: a Comparative Analysis of British and American Parent Education
}

\author{
Deborah Anne Smith Guisti \\ Portland State University \\ Ellen Turner Jurevic \\ Portland State University \\ Jane Elizabeth Mozena \\ Portland State University \\ David W. Pedersen \\ Portland State University
}

Follow this and additional works at: https://pdxscholar.library.pdx.edu/open_access_etds

Part of the Educational Methods Commons, Family, Life Course, and Society Commons, and the Social Work Commons

\section{Let us know how access to this document benefits you.}

\section{Recommended Citation}

Smith Guisti, Deborah Anne; Jurevic, Ellen Turner; Mozena, Jane Elizabeth; and Pedersen, David W., "The First Years of Life: a Comparative Analysis of British and American Parent Education" (1979).

Dissertations and Theses. Paper 2770.

https://doi.org/10.15760/etd.2766

This Thesis is brought to you for free and open access. It has been accepted for inclusion in Dissertations and Theses by an authorized administrator of PDXScholar. Please contact us if we can make this document more accessible: pdxscholar@pdx.edu. 
THE FIRST YEARS OF LIFE: A COMPARATIVE ANALYSIS OF BRITISH AND AMERICAN PARENT EDUCATION

by

DEBORAH ANNE SMITH GUISTI

ELLEN TURNER JUREVIC

JANE ELIZABETH MOZENA

DAVID W. PEDERSEN

A report submitted in partial fulfillment of the requirements for the degree of

MASTER OF

SOCIAL WORK

Portland State University

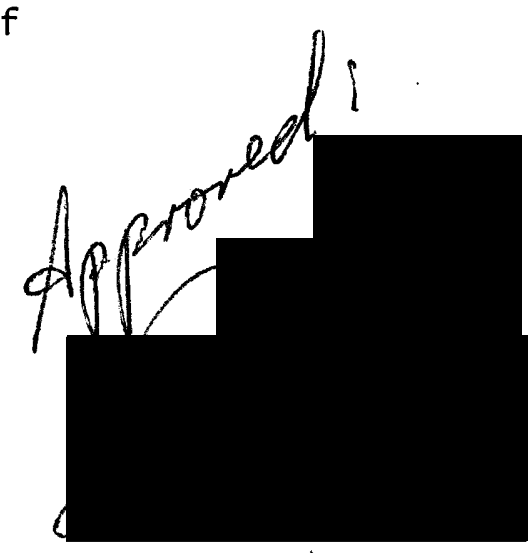

1979 
TABLE OF CONTENTS

PAGE

CHAPTER

I INTRODUCTION

Purpose of Study . . . . . . . . . . . 1

History . . . . . . . . . . . . . . 3

Philosophical Perspectives . . . . . . 6

i i Review of the literature . . . . . . . . . . 8

Introduction . . . . . . . . . . . . 8

Research on Parent Education . . . . 8

Why Teach Parenting?

When to Teach Parenting

Who Should Educate Parents?

How to Educate Parents

Conclusions

Literature for Parents . . . . . . .

Conclusion

I I APPROACH

IV ANALYSIS OF DATA

"The First Years of Life"
Development of the Baby
Parenthood

A Comparison of "The First Years of

Life" and Some Aspects of Parent and Prenatal Education in America. 
CHAPTER

$\checkmark$ CONCLUSIONS AND RECOMMENDATIONS . . . . .

PAGE

Issues

Recommendations ........... . . 74

Suggested Readings . . . . . . . . . 76

Books for Parents

Books to Read with Children

WORKS CONSULTED APPENDICES

A INDEX FOR "THE FIRST YEARS OF IIFE" $\cdot \cdot \cdot \cdot \cdot 99$

A INDEX FOR "THE FIRST YEARS OF LIFE" . . . . 90

B GLOSSARY FOR "THE FIRST YEARS OF LIFE" . . 96

C TRI-COUNTY AGENCY LIST . . . . . . . . . . . 108 
This nation which looks to the family to nurture its young, gives no real help with child rearing until a child is badly disturbed or disruptive to the community. The discontent, apathy, and violence today are a warning that society has not assumed its responsibility to ensure an environment which will provide optimum care for its children. The family cannot be allowed to withstand alone the enormous pressures of an increasingly technological world. Within the community some mechanisms must be created which will assume the responsibility for ensuring the necessary supports for the child and family. 


\section{CHAPTER I}

\section{INTRODUCTION}

There is currently an increasing demand for parent education by educators in every field who deal with child rearing. This demand is based on the idea that many problems which surface later in a person's life (and in society) result from inadequate knowledge of the development of the child. Much naiveté exists about children's growth and about how parents might interact to provide the surroundings, care, and stimulation which the infant needs. Most educators and child care professionals now believe that there is a strong correlation between the effects of the kind of parenting the child receives and later physical and emotional development.

\section{PURPOSE OF STUDY}

The purpose of our study is to analyze a British parent education program called "The First Years of Life" and compare it with some programs and educational services. of similar content in America. We hope to ascertain whether "The First Years of Life," as presented by the Open University, affords a better means of providing information than 
some programs now existent in the United States offering prenatal and parent education.

operationally defined, parent education is the purposive learning activity of parents who are attempting to change their methods of interaction with their children for the purpose of encouraging positive behavior in theirchildren (Croake \& Glover 1977, p. 151).

Our study is concerned with a specific program of parenting education and prenatal care. The program is presently being used by the Open University in Great Britain, as a short course open to the general public. Called "The First Years of Life," it is a course devised for anyone interested in learning more about prenatal care and the care of the infant and child in the first two years of life.

At the time the Open University came into existence on May 30, 1969, a variety of distance teaching methods had been planned for use in reaching many home-bound students. Television, radio, and correspondence materials, as well as records, are included in the course components.

The Open University has for the most part emphasized undergraduate studies. However, secondary, vocational, and. continuing education are seen as future possibilities in expansion of knowledge for those in vocational and special interest fields.

"The First Years of Life" is a complete course which covers the progress of the baby from conception to the end of the second year. It is a result of the efforts of the 
Open University in association with the Health Education Council.

Four television programs and four radio programs supplement eight beautifully illustrated and comprehensively planned activity books. Discussion groups are arranged to facilitate the sharing of ideas and promote better understanding .

In America we are concerned with such large-scale issues as covered by the British course, but at this time nothing comprehensive seems to have been utilized on a national level or even on a state level.

\section{HISTORY}

Historically, many individuals and organizations, both private and public, have been involved in educating unlimited numbers of parents (Croake \& Glover 1977, p. 151). The phenomenon of parent education is very old. The first record of a parent group meeting in America dates back to 1815 . Maternal groups (associations) met regularly in study groups prior to 1820 to discuss problems related to rearing children. Initially these meetings were concerned with the religious and moral development of children. During the $1800 \mathrm{~s}$ several magazines and other mass media appeared which dealt with child rearing. By 1888 The Society for The study of Child Nature was founded, which was a forerunner to the Child Study Association of America, the oldest organization 
in the United States with a continuous program directed to parent education.

The early twentieth century marked the beginning of federal support for parent education with the first white House Conference on child welfare in 1909 and the creation of The Children's Bureau in 1912. By 1914 provision was made for the County Home Demonstration agents, which were part of the Department of Agriculture, followed by additional provisions for women in homemaking. In 1918 the United States Public Health Service first supported programs which were oriented to health in parent education (Croake \& Glover 1977, P. 153).

The following decade found a rapidly growing population of parents seeking information and help in parenting. The growth continued with doctors, social workers, and educators collecting and dispensing materials. Several major universities soon began research and training in child study and parent education.

Immediately preceding World War II a decline was evidenced in the parent education field which continued through the war. From World War II to the present the support from public and private participants on the national and local levels has expanded the parent education efforts. At the present time parent education programs, under the auspices of schools, mental health organizations, and numerous other 
organizations are being taught by both professionals and nonprofessionals (Croake \& Glover 1977, p. 153).

Studies have now discovered a correlation (Caplan 1977 ) between early nutrition and later growth and developmental problems. For example, childhood obesity has been found to lead to a permanent increase in adult fat cells. A relationship between inadequate diet in infancy, and retardation in later life has also been proven. Further research has pointed out that depression in the earliest years is associated with many emotional disturbances in later life.

It has now been generally accepted (Keniston 1977, pp. 156-157) that prenatal care should begin during the first three months of preganancy to insure the prevention of infant mortality or other consequences for the infant which may be of lifelong duration.

The advancement of scientific knowledge and inquiry has brought about the concept of birth being a condition of health rather than pathology. New information in medicine has resulted in mortality reduction in mother and child; newborn mortality has been drastically reduced.

However, ignorance about reproductive biology remains:

Folk tales regarding child birth have passed from generation to generation, many of which have been perpetuated by the medical profession. Expectant parents have often remained victims of the reproductive process rather than participants (Cherry 1977, p. 3). 


\section{PHILOSOPHICAL PERSPECTIVES}

Despite the many scientific and technological advances, our very successes have created new problems. The rapidity and extent of change have introduced challenges which are difficult to meet. Suicides, homicides, illegitimate pregnancies (one out of five children born this year will be the child of a teenage mother), and venereal disease are rapidly increasing. Child abuse and child neglect are approaching epidemic levels throughout America. Crime and juvenile delinquency have escalated. Talbot (1976, p. 5) noted that although only 3 percent of our population is estimated to have serious, genetically transmitted handicaps, we find a significantly higher percentage of children who fail to thrive during infancy and childhood. It may be presumed that this failure is attributable to environmental deficiencies.

Parenting around the world has been the subject of innumerable studies. The ease with which one can reach the furthest corners of the earth permits us to observe, compare, and analyze the various methods and traditions which cultures employ in raising their families, as well as the myths and attitudes toward the process of procreation.

The nuclear age and its associated scientific and technological developments have facilitated means of disseminating information. The spread of this information has made possible changes in attitudes toward the physiological 
and psychological aspects of pregnancy, birth, and child care.

Our study is conceived in the belief that no one person or study can determine what is the best way to teach or learn about parenting. Indeed, it would be a disservice to the uniqueness and creativity of parents everywhere to state that there is unequivocally only one way to accomplish these tasks.

Parents have the right to bring up their children as they see fit; as long as their actions conform to the law and societal norms. However, we also must acknowledge that today's families could benefit from help in raising children. It is hoped that our efforts will result in more efficient provision of information and services regarding prenatal and early child care. 


\section{REVIEW OF THE LITERATURE}

\section{INTRODUCTION}

A wealth of information, advice, and points of view exists regarding what constitutes "good" parenting. There are also numerous ideas about how effective parenting can best be taught. Due to this vast amount of information it can be difficult for educators of parents to choose the best way to facilitate this education. It can be even more difficult for parents themselves to sift through the mass of information to find what is useful for them.

For the purposes of this study the literature will be reviewed in two sections. The first section will examine literature on parenting and parent education written for and by professionals. The second section will discuss iterature written for parents.

\section{RESEARCH ON PARENT EDUCATION}

Why Teach Parenting?

The first question to be asked is whether parents need to be taught anything at all about parenting. Not everyone thinks that parent education is necessary or advisable. Pediatrician Robert $W$. Chamberlin argues that no evidence 
exists to show that specific practices such as weaning or toilet training have long-term effects on a child's personal ity development (Chamberlin 1977, p. 588). He also states that children usualiy grow up successfully with a multitude of parenting styles being used by parents:

Certainly there was no evidence to suggest that the more "permissive" styles of childrearing were turning out large numbers of "spoiled brats," nor is there much evidence to indicate that the more "authoritarian" styles are producing large numbers of overly compliant children or children filled with repressed hostility waiting to be unleashed on unsuspecting teachers or peers (Chamberlin 1977, p. 589).

Chamberlin takes the position that different parenting styles are the result of the interaction between the personalities of parents and children. He writes that as long as the "fit" between the child and parenting style results in no problems:

- . the pediatrician [and he would probably include other professionals as well]. should avoid inflicting his favorite ideology of childrearing on parents and support what they're doing. . (Chamberlin 1977, p. 590).

He does advocate help for parents when problems arise. For example, he points out that the "difficult child" may have trouble with a "strict" or "permissive" approach unless the approach is modified to take the child's personality into account. Unless there are problems, though, parents should be left alone, since "most children can adapt to a relatively wide range of child-rearing practices without developing symptoms of malfunctioning" (Chamberlin 1977, p. 590). 
The "harids off" point of view is also presented by peditricians Alma and David Friedman. They describe a series of parental stages which correspond to Erickson's psycho-social stages for children of trust through identity. It is their opinion that:

Parents who have a healthy self-image and positive self-esteem usually progress relatively smoothly and comfortably through the five stages of parent development. This helps their children to develop for themselves a heal thy self-image and appropriate selfesteem, which serve them in good stead as they raise their own children (Friedman \& Friedman 1977, p. 572).

Arlene Skolnick, writing in Psychology Today, offers another reason for not teaching parents about child rearing. She states the opinion that the parenting role has been overemphasized and that expert advice has made parenting more difficult today than when common sense prevailed:

Since modern child-rearing literature asserts that parents can do irreparable harm to their children's social and emotional development, modern parents must examine their words and actions for a significance that parents in the past had never imagined (Skolnick 1978, p. 56).

The authors described thus far describe parenting as a generally smooth process, needing intervention only for pathology. This is in accordance with the medical model which advocates treating disease while letting the presumably healthy situation alone.

Other writers suggest utilizing parent education for certain populations due to the probability of problems faced by particular groups of parents. A term often encountered in the literature is "at risk," referring to children and 
families likely to have difficulties. Adolescent parents comprise one group considered to have "at risk" children. This is a large group of parents, and the numbers are increasing. Nearly one of every five births in the United States in 1974 was to a teenager (Honig 1978, p. 113).

Various social problems result from this situation. Pregnancy is a major factor in the high teenage suicide rate. One-half of all teenage marriages end in divorce. There is a 60 percent higher maternal death risk for teenage mothers. Economic problems are usually severe for teenage parents. Adolescent parents are often unwed, usually single mothers (Honig 1978, p. 114).

Adding to these problems is the teenage parent's naivete about child development. Expectations for development are often unrealistic. In one study, it was found that many teenage mothers thought babies sat aione at about twelve weeks; fathers often expected this behavior at six weeks. Both mothers and fathers expected babies to take their first step at forty weeks. Adolescent parents were also found to attribute intentions to their babies far beyond their developmental levels (Honig 1978, p. 117).

This lack of knowledge about child development can be especially damaging since teenage parents are more likely to give birth to premature babies, who are often at risk for developmental problems. Of babies born to teenagers the risk is four times greater than for other babies that there 
will be neurologic defects and retardation (Bruce 1978, p. 75$)$.

Much is written about the advisability of education for teenage parents and for other "at risk" parents, including those who are economically deprived or living under other stressful conditions. Numerous articles are written about educating parents who are abusive or potentially abusive to their children. Some of these articles will be described later.

It becomes apparent that there is a consensus in the field of parent education that such education is advisable in "problem" situations--for parents who are poor, teenaged, or who have "difficult" children. In that so much is written about parents with specific problems, there is an implicit assumption that other parents do not have problems, that parenting comes "naturally"; or that if it is not natural, it is at least being learned from the culture.

Other writers suggest that this is not the case, that parenting does not come naturally and that parents are not learning informally what they need to know. Another factor pointed out by advocates of parent education is that many parenting skills, often considered "innate" or "instinctive" can actually be learned or improved through education.

One study found that parents can be taught to differentiate between infant cry signals indicating birth, hunger, pain, and pleasure. Even brief training was found to be 
helpful. Of particular interest is the finding that gender did not seem to matter; men and women did equally well in differentiating between the cry signals (Gladding 1978, pp. 267-270). It is also interesting to note that high levels of empathy as measured in the subjects can interfere with the learning. The implication from this study seems to be that if parents can learn to distinguish between their baby's cries, they can probably also learn other childrearing behaviors considered to be instinctive.

The concept that impending and new parenthood constitutes a "life crisis" is another primary issue in exploring the need for parent education. One study found a high correlation between new parenthood and depression (IIfield 1977, p. 166). It is pointed out by Elaine Levin that even parents who have looked forward to their roles as parents report feelings of inadequacy and frustration (Levin 1975, p. 345$)$.

Many reasons have been cited regarding why parenting is especially difficult today. It has been pointed out that in the past, extended or large families provided the training ground for parents (Hughes 1977, p. 472). There has been no naturally occurring replacement for this training ground. Parents are basically left only with memories of how their parents raised them. These memories are likely to be distorted and may not be memories of good parenting (Wilson 1978, p. 67). 
A desire for more knowledge about parenting is felt by parents from all social classes. An instructor of the Lamaze method of natural childbirth gave a questionnaire regarding needs of parents to graduates of her class. Since this class was offered in a university setting it is not surprising that 74 percent of the mothers and 89 percent of the fathers had completed at least four years of college. When asked whether they would have $1 \mathrm{iked}$ more information about parenting, 82 percent of the couples stated that small group classes concerning problems with the new baby would have been helpful to them (Williams 1977, p. 1173). The main problems they would have liked help with were feeding, crying, and the baby's schedule. They expressed feelings of exhaustion and resentment about the unpredictability of their routines with the baby (Williams 1977, p. 1173).

Along with a lack of knowledge exists a lack of support in this country for many new parents. Many of the parents described above expressed the desire to know how other new parents were handling their difficulties such as changes in family life and problems with grandparents. Forty-six percent reported turning to physicians or friends for assistance. It is significant that one out of four had turned to no one (Williams 1977, p. 1173).

Other parents who would not be considered "at risk," but who still could benefit from moral support, are parents in dual career families, which are becoming increasingly 
frequent. One study of these families found that the mothers in particular "experienced much difficulty, e.g., great strain, guilt and anxiety with the proliferation of role demands in home and work situations" (Leahy 1977, p. $395)$.

As can be seen from this discussion, there is controversy over whether parents need parent education. However, most of the evidence in this literature suggests that all parents could benefit from some type of parent education and/or support from other parents. Perhaps the most con'vincing evidence comes from reports of parents' responses to such education. One study of expectant parent classes found that the parents believed the classes benefited both parents, increased their confidence, and reduced anxieties (Beebe 1978, pp. 55-58). One finding reported throughout the literature is that parents find the sharing with other parents one of the most valuable elements of parent education, with the discovery that they are not alone or abnormal.

\section{When to Teach Parenting}

It has been pointed out that the ". . periods of pregnancy, birth and early infancy are critically important times for parents and infants to learn about each other" (Brazelton 1978, p. 27). In a similar vein, another article states:

Available evidence indicates that the first three years of a child's life--a time for establishing 
enduring, healthy parent-child relationships--is a critical time for parent education (Charniey \& Myre 1977, p. 12).

In light of the above statements, it is important to note that few educational programs have been developed to help parents during this time. Many programs described in the 1 iterature are for expectant parents who are apparently left to their own devices after the baby is born. Perhaps they receive help during the preschool years; but these later programs are often addressed to "problem" situations or "problem" children.

A few programs are described for these times. One such program takes place during the hospital stay following childbirth. Teaching is performed by other mothers, "peer models," who show how to make formula and how to take care of the baby. These classes take place in the patients' rooms, where the mothers all join in the group discussion (Johnston et a1. 1977, pp. 994-995).

Another program described to help new mothers is one in which nurses made a series of home visits for several weeks after the baby was born. The visits were ostensibly for research on breast-feeding; but the most important discovery of the study was how much the mothers seemed to need someone to talk to and to answer their questions. "Many mothers prepared lists of questions before the nurse's visit, others occurred spontaneously" (Brown \& Hurlock 1977, p. 439). 
It is pointed out in this study that almost all nonWestern cultures as well as many mammals, have individuals, usually female, who are available for help and emotional support during pregnancy, delivery, and the newborn period. The Greeks had a name for these female assistants, which was "doula." It is noted that:

. . these cultures always have breastfeeding. Few of these women fail to nurse successfully. Our culture's failure to supply a "doula" for the nursing mother may be largely responsible for the high failure rate in achieving a successful nursing relationship with their infants (Brown \& Hurlock 1977, p. 439).

The conclusion of the study was that the mothers needed a "doula."

The nurses working in the study intuitively accepted this role and felt comfortable in it. Mothers always expressed gratitude for the nurse's presence... (Brown \& Hurlock 1977, p. 440).

It appears from this study that the newborn period is indeed an important time for education and emotional support.

As mentioned previously, much of the research on parent education deals with the preschool years. One study described a program for parents of children two and onehalf to seven years of age:

The nursery school is a normal, non-threatening setting in which to reach parents at the critical time when they are actively involved in the early development of their preschool children (Atkeson \& Guttentag 1975, p. 515).

This statement seems to imply that parent educators must somehow "sneak up" on parents to get some education into them while they are "actively involved" with their children. 
The fact that the words "normal" and "non-threatening" are used suggests that parent education is not considered normal and that it is threatening.

It is argued by some authorities that parent education needs to be taught before parents are even considering parenthood, in high school or even junior high school. One study found that adolescents' self-acceptance and selfesteem were enhanced by teaching them about "family life education" which included information about being a parent (Crosby 1971, pp. 137-140). Another study found that attitudes of adolescents were extremely pliable during the period between fourteen and sixteen years of age (Moerch \& Becker 1971, p. 71). This seems important in terms of the large number of teenage pregnancies described earlier.

In terms of the timing for education on parenting it is important to realize that different concepts are more readily absorbed at different times. When the parents described earlier who requested more education following the Lamaze prepared childbirth course were asked what information they would have wanted before delivery, 58 percent responded "nothing." "It may be that parents can benefit most from infant care and behavior information after they've taken the baby home" (Williams 1977, p. 1173).

Another study regarding the timing of parent education measured the differences between the knowledge attained by parents and non-parents who studied Thomas Gordon's "Parent 
Effectiveness Training" (PET) course. Findings indicated that PET leads to shifts in attitudes toward a more liberal set of beliefs for parents and non-parents, in middle-class white females with some college training. It was also discovered that the impact was greater on the students who were parents. In fact, those parents who only read the book showed attitude changes as great as non-parents taking the entire course. The relevant experience of being a parent greatly influenced learning (Mitchell \& McManis 1977, pp. $215-218)$.

It appears from these studies that there are optimal times for learning certain concepts. Rather than there being a "correct" time for education about parenting, these studies suggest instead that different concepts are optimally learned during different periods.

It has also been pointed out that it may be helpful to learn. some things more than once. In a study of attitudes toward expectant parent classes, it was found that those parents who were "reasonably sure of their knowledge were not threatened by the classes. In fact, the classes had a reinforcing quality which they liked" (Beebe 1978, p. 57).

One suggestion offered is that education about parenting take place throughout life. Such education could be provided throughout the various stages of parenthood/ 
childhood, from preschool into grandparenthood (Price-Bonham \& Skeen 1979, pp. 53-59).

\section{Who Should Educate Parents?}

Some authorities suggest that parents should be taught by other parents. It has been found that pregnant women in many cultures traditionally reject the physician and nursel midwife and turn to other women, particularly mothers, grandmothers, or aunts for advice on how to care for the baby (Johnston et al. 1977, p. 994). Burton White agrees with this practice, suggesting that experienced mothers are better able to help parents than professional persons (Nichols 1977, p. 35).

A problem with this concept can be that child care practices have changed sufficiently over the past few years so that new mothers do not always get the help they need from other parents in the environment. For example, a mother who bottle-fed her baby twenty years ago may not be prepared to answer her daughter's questions about breastfeeding (Johnston et al. 1977, p. 994).

Several studies have been conducted regarding qualities of potential educators on parenting. The most important considerations shared by those studied was that an accepting attitude and tolerance of various ideas were the most important characteristics of the teachers, more important than knowledge about the subject (Whatley 1973, pp. 139-198; Fohlin 1971, p. 234). If the teacher is a parent, 
it might help; but these studies suggest that it is probably not necessary.

As mentioned previously, the consensus of the authorities is that parent education should be conducted in groups. It would seem, therefore, that the most important characteristic of the educator could be an ability to facilitate the sharing of feelings and ideas between parents.

\section{How to Educate Parents}

While some controversy exists about what to teach expectant parents, there is considerable controversy about how parents should be educated. In regard to teaching parents how to raise their children, there are many types of programs offered. One important consideration is that in order to be effective programs should vary in relation to the needs of different types of parents.

One area in which differences between parents have been noticed is between parents from different social classes. Working-class parents have been described as more "traditional" and more "authoritarian" in child rearing than middle-class parents. Obedience to parental demands is more likely to be stressed in working-class families. It has been pointed out that an authoritarian parenting style might suit the needs of some children in adapting to their world (Brown 1979, p. 67). It is suggested that the parents' occupations may hold one explanation for the class differences: 
Middle-class occupations require greater degrees of self-direction, whereas working-class occupations involve to a greater degree the following of explicit rules set down by those in authority. Therefore, parents from both social classes are preparing their children to survive in the world as they know it (Brown 1979, p. 68).

It would seem that if these two groups of parents have different parenting styles, they would respond more readily to different types of parent education. Two popular approaches are democratic and non-authoritarian. These are the Rudolf Dreikers/Adlerian approach using Children: The Challenge and the Thomas Gordon approach using Parent Effectiveness Training. Both of these methods encourage reflective listening and democratic reasoning with children. These approaches are geared for middle-class parents. As might be expected, middle-class parents respond to these methods; working-class parents often do not (Hughes 1977 , p. 474). Behavior-modification approaches may be more acceptable to working-class parents (Hughes 1977, p. 474).!

Another important point to realize is that parents who have a lot of personal problems themselves may not have the resources to learn about understanding their children:

If parents are overwhelmed with financial stresses and are worried about paying the rent, how much attention can they be expected to focus on learning to promote their child's cognitive development?

(Wilson 1978, p. 71).

Ann wilson describes a hierarchy of parenting needs, ranging from an understanding of the significance of one's own childhood to having self-confidence as a parent. She 
suggests that some parents may need help for themselves before they can be taught the "crafts of parenting" (Wilson 1978, p. 72).

This seems especially true for adolescent parents, who may have a multitude of problems. They are more likely to be parents of children with developmental or other problems. They are also likely to have problems with their own parents, as dramatically illustrated by the story of one young mother who described how her mother would yell at her, "Your accident is crying. Go and take care of it" (Honig 1977, p. 115).

It is also necessary to understand why some of these girls become pregnant: so they can have someone to love and be loved by, or so ". . my boyfriend will really love me and stay with me.." (Honig 1977, p. 116). It is also likely that these adolescent parents have been the products of poor parenting themselves.

One must also realize that these parents are simply physically and cognitively immature:

One report on social worker observations of a group of 12 to 20-year-old adolescent girls from lowincome families found the girls had very short attention spans, were in perpetual movement, found it difficult to tolerate frustration, had intense conflicts so that it was difficult to arrange a meeting with the mothers... (Honig 1977, p. 116).

These young mothers had not begun to think of goals, of what they would be doing ten years from now. These adolescent parents need long-term support: 
Someone who feels overwhelmed, rejected, bewildered and frustrated in her move toward her own life goals for herself by an unwanted pregnancy will find it hard to summon up the sustained 1 ife energy and tender caring feelings that high quality infant caregiving and parenting requires (Honig 1977, p. 119).

These parents require much more than classes on parenting, a) though they need help with that part of life too.

Another group of parents to be considered is that of abusive and neglectful parents. One important consideration is that these parents are often unwilling and afraid to. seek help. It is often necessary to reach out to them. One program used "family developers," paraprofessionals who visited abusive parents in their homes. Then, after awhile, these parents were introduced to parent groups. They were initially paid two dollars per session (Thistleton 1977, pp. $513-515)$.

It is reported that much of the abuse and neglect occurs because of inappropriate age expectations (Thistleton 1977, p. 517). It would seem that parent education could effectively help these parents, then, by teaching them about child development. It was also found that it is typically preschool children who are abused (Thistleton 1977, p. 520). This is important since, as noted previously, little parental education occurs between birth and preschool to prevent this from happening.

Another type of program involving reaching out used modeling to teach low-income rural mothers. College students majoring in nursery school education paid home visits 
to mothers to demonstrate various child-rearing skills to them. The mothers also contributed something by helping the students with their education. Another component of the program included weekly meetings for ten months. It is significant that none of the mothers dropped out of the program or missed more than two meetings (Goodman 1975, p. 10).

This study suggests that some parents need to be reached by visiting with them in their homes, and that they are often enthusiastic learners once they are reached.

A group of parents which has been neglected for far too long comprises one-half of all parents--fathers. One aspect of the father-child relationship being considered recently concerns "bonding." Bonding is the process generally believed to take place during the first six months of a child's life when parent'and child form an attachment to one another. This attachment is considered by many to be crucial to normal psychological development and is usually described in terms of mothers and their babies.

It has been pointed out that bonding is important for fathers and their children, just as it is for mothers. For this bonding to occur, it helps if the father is involved during the prenatal period as well as during delivery. It is important for the father to have olfactory, tactile, and emotional contact with the baby (Lamb \& Lamb 1976, pp. $379-385)$. 
As is the case for mothers, parenthood can be seen as a crisis for fathers. Approaching fatherhood can trigger depression. It can lead to rivalry and competition for his partner's affection, can close off escape from a bad marriage, bring up unfinished business with his own parents, bring on financial worries, and worries about parenting responsibility and capability (Coley 1976, pp. 359-363).

It is significant that fathers are usually left out of parent education offered after the baby is born. Aside from the preparation for childbirth classes, there is little reference in the 1 iterature to fathers receiving parent education. It has been noted that the preparation for childbirth classes does not help significantly with the shift to parenthood (Wente \& Crockenberg 1976, p. 351). Parenting classes often explicitly or implicitly exclude fathers. Sometimes they are called "mothers" groups; sometimes the time of day they are held excludes fathers. There is also little community encouragement given to fathers to participate in parenting. Support is usually lacking at work, with little paternity leave and few flexible hours offered by employers (Fein 1976, pp. 341-347).

In studying the different groups of parents and what types of education work best for each group, it is also important to remember that differences do not always exist between groups and that differences are sometimes contrary to stereotypes. For instance, in a study comparing Black and 
White fathers it was found that Black middle-class husbands participate more in child rearing than White middle-class husbands and that they also emphasize affectional techniques to a greater extent. (Price-Bonham \& Skeen 1979, p. 54). However, it is pointed out that Black middle-class fathers are usually overlooked in the emphasis on fatherless homes among the Black population (Price-Bonham \& Skeen 1979, pp. $54-55)$.

Middle-class Black and White fathers were found to be similar in most respects in regard to their parenting. They did not differ in the use of spanking, withdrawing privileges, isolating their children, or in the frequency they explained the reason for discipline. It was found that White men need to learn to enjoy their children more and express nurturing and affection. Black men, in contrast, need role models and education emphasizing more facets of the "instrumental" role, which includes vocational aspirations. It has been suggested that parent education groups include both Black and White fathers, in order that they can learn and share from each other (Price-Bonham \& Skeen 1979, p. 55).

One important point in examining what parents are like is to realize that they are often not like the stereotype of the "typical" family, with two parents and two children. In fact, more than one-half of American families today do not fit this ideal. (Smoyak 1979, p. 449). Therefore, parent 
programs designed for "special" cases, such as for single parents, may not be so special as is commonly believed.

It should also be kept in mind by designers of parent education programs, who are likely to be middle class and college educated, that the parents they are attempting to reach may not share their background and orientation. For example, in one study more "accommodative" mothers were found to be from middle-class families and have four-year college educations. Yet, recent census figures show that only 10 percent of the general population has this much education; and of this small number, less than half are women (Chamberlin 1977, p. 586).

Along with knowing what parents are really like with an avoidance of stereotypes, it is also necessary to know what parenting behavior is really like. In a study of discipline of children in public places it was found that 72 percent of the middle-class parents and 82 percent of the working-class parents studied used disciplinary techniques such as hitting, yelling, and direct commands (Brown 1979, p. 68). This type of discipline was undoubtedly more restrictive than that used at home because parents seem to view misbehavior in public places as "emergency situations" (Brown 1979, p. 70). The point is, however, that it seems important for parent educators to realize how parents actually do parent their children. For example, this study 
suggests that resistance might be encountered in programs where parents who spank are labeled "bad."

A related implication from this study for parent education concerns the importance parents place on appearing to be "good" parents in public. The stigma of the misbehaving child appears to influence parents in the types of discipline they choose:

If we are to convince parents that there are effective alternatives to the art of restrictive discipline techniques, then we must work towards debunking the myth that "there are no bad children, only bad parents." In other words, until parents' seifesteem becomes less dependent on the behavior of their children, they will hesitate to use those autonomy-granting discipline techniques, which are integral to parent-effectiveness training programs because they take much longer to implement (Brown 1979, p. 71).

Brown seems to be suggesting that some basic changes in attitudes about parents and children are necessary in this country before some parent education methods can be effective.

\section{Conclusions}

Perhaps the most important conclusion which can be drawn from the research on parent education is that this education is "too little" and often "too late" (Luckey 1978, p. 70). There is a significant gap in parent education between the birth of the child and the time the child is age three, even though this has been described as a crisis period in parents' 1 ives. 
The literature also suggests that parent education be tailored to fit particular parents' needs. Middle-class, working-class, and adolescent parents seem often to have different interests and different needs to be met by parenting programs. It is suggested that abusive and neglectful parents often will respond to outreach efforts. One change which is taking place is that fathers are increasingly being studied by researchers and are beginning to be more involved in parent education.

In looking at different groups, it is also important to keep in mind the variations between individuals within these groups. For example, it is pointed out that a thirteen-year-old girl who does not know the father of her child is likely to have more and different needs than a seventeen-year-old mother who plans to marry the father of her child upon graduation (Honig 1978, p. 115).

There appear to be optimal times for learning certain concepts, but not one perfect time for parent education as a whole. It seems that education for parenting can take place on different levels throughout life.

A bewildering array of parent education programs are available. In fact, parent education has been referred to as "big business" (Charnley \& Myre 1977, p. 21). One thing practically all of these programs agree on is that parents should be educated in groups, that the group support is an enormously important element. 
Finally, for strong participation in parent education to occur, it appears that the stigma needs to be lifted from this activity. This seems unlikely to happen as long as such education is viewed as needed only for parents with "problems." Perhaps a better way to put this is to say that for such a change to occur parents and society as a whole must learn that it is "normal" to have "problems," particularly in so complex an endeavor as parenting (Levin 1975, p. 344$)$.

\section{LITERATURE FOR PARENTS}

Numerous books have been written for parents dealing with the pregnancy experience. One of these referred to often is Pregnancy. Birth and the Newborn Baby by the Boston Children's Medical Center. One-third of the book deals with the newborn baby; the other two-thirds of the book is devoted to prenatal concerns. There is emphasis on both physical and emotional changes during pregnancy.

Another book about pregnancy is Nine Months to Go by Robert Mitchell and Ted Klein. It is a practical guide to pregnancy with advice about health and diet, maternity clothes, and what to take to the hospital. Emotional considerations are mentioned briefly. Five pages in the middle of the book are devoted to fathers, with an apology for not mentioning them sooner. Sexual relations are discussed in 
this section along with adjustment to fatherhood (Mitchell \& Klein 1960, pp. 111-115).

Many expectant parents obtain prenatal information from pamphlets they receive at preparation for childbirth classes. Many of these pamphlets are put out by various organizations like the March of Dimes' Be Good to Your Baby before It Is Born. A somewhat lengthier booklet provided by expectant parent classes is Prenatal Care, published by the U.S. Department of Health, Education and Welfare. These pamphlets generally discuss physical care of the expectant mother during pregnancy. Brief attention is paid to emotional considerations surrounding the transition to parenthood.

The Prepared Childbirth Association has its own Parent Manual. It basically discusses physical changes in pregnancy and care of the expectant mother, with instructions about childbirth. There is also a short section discussing what it is like after the baby is home; some helpful hints are offered. Feelings about birth and the new baby are mentioned briefly.

Once the baby is born, parents have a multitude of reading material available. The most popular books over the years have been the federal government's Infant Care and Dr. Benjamin Spock's Baby and Child Care. It is significant to note that as of 1973 the number sold of each of these books 
nearly equaled the number of American babies born (Bane 1973, p. 669).

Dr. Spock begins by telling parents to enjoy their babies and not to be afraid of them. Basically, he attempts to put parents at their ease, and offers common-sense advice. Perhaps the most useful and comforting element of the book is the great detail about everything from how to change a diaper to what to do when the baby becomes ill. Parents' feelings are also dealtwith throughout the book. In a section called "Parents Are Human" he points out that "there's a lot of hard work and deprivation"; he also stresses the normalcy of parents' mixed feelings about their baby (spock 1968, pp. 17-28). Dr. Spock also has sections dealing with special problems such as parenting handicapped children and adoption.

The booklet Infant Care also contains much practical advice for new parents. There is also a discussion about discipline. One section attempts to reassure parents of "difficult" babies:

While no single trait of temperament makes a baby much more difficult, babies with certain combinations of traits are certainly harder to care for. If you have such a child it may be a great comfort to know that you really have a much harder job than do most other mothers (Infant Care 1973, p. 27).

other books written for parents have particular emphases. One of these is The First. Twelve Months of Life by Frank Caplan. It covers aspects of child development and tells what parents can expect of their children at different 
stages. There is also some attention paid to parents' feelings and concerns. As is true with many other writers, Caplan basically addresses comments to mothers and uses the term "mothering." Caplan has also written a book called The Second Twelve Months of Life.

Burton White's The First Three Years of Life also focuses on child development. This book could prove useful for some parents. It follows a chronological format in describing child development, with no information on prenatal development. It is important to note that white addresses a highly educated reader. His book is also long and visually unappealing; there are few pictures, although he does include some charts. He also deals almost exclusively with normal development, having little to say about the handicapped or underdeveloped child.

Your child from one to six is a short book obtainable from the U.S. Government Printing office. This book provides an overview of physical growth patterns, language development, and social development. Practical advice pertaining to various developmental stages is offered to parents throughout the book. There is also a useful discussion of special problems including fears, separations, fighting, and the handicapped child. The book suggests parents seek help if there are problems they feel they cannot handle, advising that "children don't often outgrow their problems-only their clothes" (1977, p. 92). 
Another book focusing on child development and child rearing is Eda LeShan's How Do Your Children Grow? This book provides an overview of child development and parental concerns. from the periods of infancy through adolescence. The book is based on a television series of the same name which aired on WNET/Channel 13, New York. The author suggests that the

- . best education for parenthood occurs when parents try to search out their own fundamental values --their philosophy of life--a point of view about the Human experience" (LeShan 1971, p. 25).

There are also books which focus primarily on behavior management with children and relationships between parent and child. One of these books is How to Parent by Fitzhugh Dodson. "How to Mother" might have been a more appropriate title since he speaks directly to mothers. Although he mentions briefly such practical matters as feeding and diapering, the primary emphasis is on discipline and on enhancing the child's emotional and cognitive development. Dr. Dodson has also written a book called How to Father, perhaps in realization that his other book left fathers out.' Both books have ideas useful to either parent, however, if they can ignore his sex-role stereotyping.

What Every Child Would Like His Parents to Know by Dr. Lee Salk is focused on enhancement of the child's mental health. This book is practical and easy to read with much common-sense information to assist parents in understanding 
and helping their children with problems experienced in growing up.

Dr. Benjamin spock has written a book for modern parents called Raising Children in a Difficult Time. "This book addresses the special problems of living in the world of today with its high divorce rate, high level of crime, alcoholism, delinquency, drug abuse, mental illness, and suicide. Acknowledging these difficult times, spock advises parents to do the best they can to trust themselves and their intuitions. He attempts to lessen feelings of inadequacy and increase parents' enjoyment of their children.

Other books concerned with the parent-child relationship are Rudolf Dreikurs' Children: The Challenge, Thomas Gordon's Parent Effectiveness Training, and Haim Ginott's Between Parent and Child. These writers all emphasize communication between parents and children. Ginott is best known for his encouragement of the expression of feelings by both parents and children; he believes that all feelings are acceptable.

Child Behavior by Frances IIg and Louise Bates aiso provides information about behavior management. A "how to do" type of resource, this book provides specific advice on what to do about behavior problems which parents face in everyday life. This book provides an excellent description of developmental stages and appropriate behaviors by age in the first ten years of 1 ife. 
A widely used book is Gerald Patterson's Families. Patterson describes an approach to child rearing based on learning theory and concerned primarily with discipline. This book is often used in classes for parents of children exhibiting behavior problems. It has useful suggestions for all parents, however, about how to modify their children's behavior through a knowledge of reinforcement.

These books on child mariagement and parent-child relationships are generally addressed to parents with children older than two years of age. They deserve mention here, however, because parents of younger children often read them anyway, particularly if they happen to take a parenting course.

As can be seen from this review of books for parents, many of them specialize in various aspects of child rearing. One that does not specialize is Frank Caplan's The Parenting Advisor. This book is 542 pages long and deals comprehensively with both prenatal and child rearing concerns. The book represents an attempt to synthesize the current research on parenting; it seems useful to parents and professionals alike. Many points of view are expressed on a large number of topics. Then, the authors take a stand and present their own perspective on each issue. The Parenting Advisor addresses practical concerns such as feeding and diapering along with information and advice about the parentchild relationship, emotional development, and discipline. 
Some attention is also paid to parents and children with special needs. This book would probably appeal most to well-educated parents.

One other book worth mentioning is Parents' Yellow Pages, another book by Frank Caplan. As suggested by the title, this book is a "telephone book" type of resource. It contains information covering 130 subjects with information on facilities, periodicals, catalogues, and other services that are provided.

In reviewing the literature available to parents, it is necessary to include information available in the "popular 1 iterature" of magazines. Magazines have been widely used by parents as a source for education on child rearing. In fact, one magazine, Parents, focuses exclusively on the parenting role. One study looked at articles for parents in three popular women's magazines between the years 1950 and 1970. The magazines studied were Ladies Home Journal, Good Housekeeping, and Redbook.

It is of interest to note that the majority of articles examined focused on the early childhood years ( 43 percent). Only 11 percent related to infancy (Bigner 1972, p. 315). This is consistent with the majority of the riterature about parent education which suggests that the preschool period is the time considered most important for providing information to parents about raising children. 
The ever-popular Dr. Spock was found to be a consistent and heavy contributor to Ladies Home Journal and Redbook. As in his books, a recurrent theme in his articles concerned bolstering parents' confidence to handle their relationships with their children (Bigner 1972, p. 315).

An interesting change was noted during these years regarding the role of the father. Whereas very little was expected of fathers in terms of a parenting role in 1950, this changed a great deal during these years. While equality in parenting was seldom mentioned, fathers were increasingly encouraged to participate "as much as possible," the suggested result being better personality development of the child (Bigner 1972, p. 316).

It is not surprising that the subject of discipline received the greatest amount of attention in terms of advice giving in these magazines. The primary piece of advice discouraged physical punishment. It is also interesting that as far back as 1950 authors in these magazine articles were emphasizing what is currently known as behavior modification (Bigner 1972, p. 317).

A popular concept during the 1960 s was the parent as "expert." Many magazine articles dealt with the common theme, "Experts don't know any more about raising children than I (the parent) do" (Bigner 1972, p. 316). It is pointed out that the parent as expert idea never really did catch on, as is shown by the continued popularity of such 
individuals as Benjamin Spock and Haim Ginott (Bigner 1972, p. 316). It may be speculated that the "parent as expert" idea might even have been harmful to parents' self-concepts by suggesting that parents should intuitively know what to do when parents themselves knew that in reality they lacked this knowledge. It seems reasonable to think that this attitude may have helped to increase the stigma currently surrounding parent education as something "normal". parents do not need.

After reviewing some literature for parents, one author concluded that parents do indeed want and need education and guidance about child rearing. The vast number of books written on the subject attests to this. "Child care books obviously respond to the needs of parents; if they did not, people would stop buying them and writers would stop producing them" (Bane 1973, p. 669).

Parents need practical advice to help them with their difficult tasks (Bane 1973, p. 671). What is more, "parents, like everybody else, al so need reassurance and support" (Bane 1973, p. 671). The literature provided for parents offers a vast amount of information in both of these areas. The problem for parents may be in finding this information and in selecting from the many specialized resources in this country. 


\section{Conclusion}

The expressed need by parents for assistance with the difficult tasks of child rearing is of crucial importance when considered in 1 ight of the research described earlier. our research on American parent education revealed many gaps as well as fragmentation in services and written materials available to parents. The myth of the self-sufficient family and the stigma associated with having "problems" are deterrents to parents from seeking what services do exist.

Parent education is an important field of service for social workers. The family has long been recognized as the specialty of social work. Social workers are wel1-trained in human development as well as in family dynamics. The consensus of authorities that parents are best educated in groups also suggests that social workers have much to offer parents as group facilitators sensitive to the emotional needs of group members. Social work shares with its related professions of education, psychology, psychiatry, and medicine the responsibility for helping parents and children to grow in these difficult times. 


\section{CHAPTER III}

\section{APPROACH}

This study analyzes a specific program of prenatal and parenting education titled "The First Years of Life." The course is currently being offered by the Open University in England.

"The First Years of Life" is compared with specific aspects of some American programs of parent education and prenatal care. An extensive review of the literature and a study of selected programs of parent education in the greater metropolitan area of Portland, Oregon were utilized in the comparison with the Open University course.

The population addressed by "The First Years of Life" is the parents and their children from the time the decision to conceive is made, or the prenatal period in other instances, to the time the child is two years of age. Prenatal and postnatal parenting and child development are the specific areas covered in the literature reviewed.

The initial undertaking of the research project was to analyze "The First Years of Life" for feasibility and suitability for use in the greater Portland metropolitan area. The entire content of "The First Years of Life" resource packet was read and reviewed by all members of the research 
team. Concepts and ideas were discussed and evaluated as to their appropriateness and accuracy. The course's written material was reviewed for adequacy of content.

For comparison the 1 iterature commonly used in the United States was also reviewed for content and comprehensiveness. It was determined that "The First Years of Life" would be a resource if it were adapted for suitability in the local area. It was further determined that the target population addressed by the adaptation would be parents and expectant parents. The task involved in the adaptation included the preparation of a comprehensive glossary, index, and community resource i ist. The concepts presented in "The First Years of Life" were edited for clarity and accuracy. The glossary clarifies British terminology which may be unclear to American readers. The index allows for easy access to all the information included in the written part of the course.

It was necessary to describe and assess the information in "The First Years of Life." The research team utilized the course outline, as well as a listing of basic themes, for organizational purposes. This information was then compared to American 1 iterature on parent education. To establish a basis for the review of the literature and for the resulting bibliography, a variety of resources was utilized. The Medline computer at the University of Oregon Health Sciences Center was consulted for parent education 
information. Relevant journals were reviewed. Bibliographies from popular texts in this field were consulted.

Personal contact was made with early childhood educators and social service agency personnel for books and articles relative to the parenting tasks.

Each research team member reviewed a portion of the literature on parent education. Notes were taken for content, and discussion was utilized for analysis.

The research team developed a questionnaire to determine what parent education and prenatal services were available in the greater Portland metropolitan area. Four agencies concluded by the research team to be obvious resources for the general public were chosen to be administered the questionnaire. These agencies included the Tri County Community Council, the child Care Coordinating Council, the Multnomah County Health Department, and Parent-Child Services. Each agency was contacted by each team member presenting himself/herself as a parent anticipating a first child. Information was sought regarding prenatal and postnatal care, child development, and parenting skills. The agencies responded with a variety of information. The names and telephone numbers of eighteen agencies were offered to the researchers as suggested resources. There was little overlap or consistency in the referrals made. The research team concluded that the services are randomly and disjointedly presented to the public. A decision was made that 
further exploration of the service delivery system would be best studied in a separate analysis. A detailed listing of local resources indicates ninety-two agencies which potentially offer parent education services in the greater Portland metropolitan area (see Appendix C).

Parent education on a mass basis, such as the open University course, offers a significant area for social work practice. Education of this nature supports and endorses social work values. The Open University course is available to all people on an equal basis; providing an opportunity for people to learn through a variety of methods, i.e., reading, television, radio, and discussion groups. The paramount value of such education concerns the preventative aspect. It is the belief of the research team that many social problems can be diverted through parent education. A course such as "The First Years of Life" provides an opportunity for learning about parenting to the general population. The motivation for study and adaptation of such a course lies in the educational opportunities it could afford to so many people.

The research as well as the writing involved with this study was assigned to individuals within the team. Open discussion was utilized for evaluation as well as editing the content. Rewriting followed the editing process. One team member was utilized for the final editing process, to 
assure consistency and cohesiveness of style throughout the paper. 
CHAPTER IV

ANALYSIS OF DATA

"THE FIRST YEARS OF LIFE"

"The First Years of Life" is the title of a course on child development from conception to age twenty-four months, and parenthood. Great Britain's Open University sponsors the course in conjunction with the Health Education Council. The curriculum material consists of eight books which are addressed directly to parents, four television programs, four radio programs, and a resource pack. This pack contains records, leaflets, posters, and assignments, all of which relate to the course. The Open University prearranges discussion groups for course participants and makes them available to those who are interested. The Open University strongly recommends these groups.

"The First Years of Life" is a self-discovery course; it was established to help parents decide how to get a child started in the right direction:

The course is all about the kinds of real-life questions and problems that every parent has to cope with. But if you are expecting to find rules and right answers you will be disappointed. . . We are going to help you think things out for yourself (Book I, P. 5*).

*The preceding note and all subsequent notes in this section--"The First Years of Life"--refer to the eight books 
The books consist of specific articles which address. a multitude of parent education issues. The course material is coherent and nontechnical; the language is easy to understand. There are colored photographs and pictures throughout the books; charts or exercises accompany most of the articles.

The material in this course addresses two general themes--development of the baby and parenthood; it is presented in a chronological order. The first book deals with conception and early pregnancy while the last book concerns itself with child development from eighteen to twenty-four months. For the purpose of this analysis, these two basic topics--development of the baby and parenthood--will be utilized.

The course material contains numerous articles, exercises, and questionnaires along with general information. These exercises should help parents work out answers for themselves which fit for the individual; they are designed to increase self-awareness, as well as understanding of one's baby:

The activities themselves merely provide starting points and you and your baby will go on to invent more of your own. Some of the questionnaires that help you find out about your views are also only starting points and you will move on from these (Book VIII, p. 31).

by the same name. These notes will be identified as follows: (Book number, page number). 
At this point it seems useful to look at the course material in its chronological order before moving on to the examination of general themes. The books begin with an explanation of how a woman's body functions and the changes that occur during pregnancy. The first book, "A New Life," deals primarily with conception and early pregnancy. The second, "Progress in Pregnancy," discusses preparation for childbirth and changes during pregnancy from three to nine months. "Birth and the Newborn Baby," the third book, concerns itself with the process of birth and the first two weeks of $1 \mathrm{ife}$. The fourth, "Making Patterns," focuses on the baby from two weeks until three months. The fifth book, "Coming to Grips with It All," describes development from three to six months of age. "Who's in Control," the sixth book, emphasizes the period from six to twelve months; it addresses such issues as trust, baby-sitting, and safety. "Happy Families" is the name of the seventh book and it discusses the period from twelve to eighteen months. The eighth and last book, "Widening Horizons," takes us up to twenty-four months of age; it deals with such issues as toilet training, fears, and discipline.

The course attempts to help parents understand what is involved in having and raising children; it is not meant to be memorized, but rather to serve as an adjunct to common sense:

We are not aiming to produce perfect parents with perfect babies. We realise that there's no such 
thing. The trouble is that a tired or irritable parent with a grizzly and difficult baby starts thinking that other parents cope better and that other babies are easier to deal with. This is a feeling that all parents have at times. Most just don't like to admit it (Book I, p. 5).

Baby development and parenthood are the basic themes of The First Years of Life. Subdivision of these two areas aids in clarification of the material which the books cover. The books break development of the baby into five areas: child's health, physical growth and development, emotional/personality development, development of thinking and the senses, and language and social development. There are four specific areas of parenthood: parents' health, parents' relationship, parent-child relationships, and health, social, and voluntary services for families.

Although the books focus on healthy babies and healthy parents, they make many references to potential problems. They suggest consultation with the doctor whenever parents are concerned about their baby. One discussion of possible problems is meant to make parents aware that all babies are not heal thy:

It would be fool ish to pretend that (serious abnormalities) do not occur; so we think you should know about them and be aware of many things that can be done to prevent a possible tragedy (Book II, p. 20).

All of the topic areas overlap and mingle with one another; no distinct boundaries separate them. Nevertheless, it is more manageable to separate the subject areas so one can study particular concerns or interests. This 
analysis will highlight each of the topics and utilize numerous direct quotations so the reader might gain an understanding of the content in The First Years of Life.

\section{Development of the Baby}

This basic theme deals with child development, before birth through the first two years of life. Among other concerns, development of the baby deals with the baby's health. The books address such issues as the effects of drugs and smoking during pregnancy; possible fetal abnormalities and special tests in pregnancy; physical features of babies; accidents and safety; childhood illnesses and immunization. This information is straightforward and easy to understand:

Your child is offered immunisation to protect him against infectious diseases, some of which could be fatal. These diseases are rare nowadays, but only because most children have been immunised in the past. Today fewer children are immunised and there are signs that we may face major outbreaks of the diseases again (Book V, p. 26).

As well as information, there are exercises to help parents understand various aspects of children's health. An excellent example of the exercises utilized in the course is one called "Does it Matter What He Eats?" (Book V, p. 20). It concerns itself with force-feeding a baby and suggests that parents force-feed each other to experience this situation.

The First Years of Life covers physical development of children extensively. Discussion of prenatal development includes such topics as conception and how it occurs, as well as in utero fetal growth with colored pictures and 
detailed explanations. This area also includes descriptions of prematurity and tiny babies. Physical development covers such areas as body. control, sitting, walking, eating, and nutrition. The books point out developmental milestones such as sitting, walking, and talking. They also stress "stepping stones" such as modeling behavior and selfrecognition in a mirror; these are described as important growth achievements (Book VII, p. 3).

Consideration of parental concerns and emotional reactions to child rearing are important aspects of the course:

Our anxiety, which needs constant reassurance that our child is doing well, can lead us to expect him to do far too much for his age. Most dangerous of all, this anxiety can turn into anger (Book. VII, p. 3 ).

Babies progress and grow at very different paces; the books offer advice so parents can understand their baby's physical development. Throughout the books there is discussion of developmental norms and advice to parents to ask their doctor or health visitor about any worries:

Children vary so much that giving exact dates or comparing your child with a neighbour's child is of little help. Baby clinics like to give all babies regular developmental checkups at six weeks, six months, and then every following six months. If you are worried about your child ask your health visitor's or doctor's advice--they know and can examine your child (Book VII, p. 3 ).

An article under physical development also discussed toys for children under two years. 
The baby's emotional health and personality development are topics which come under development of the baby. In this area are discussions of why babies cry, development of trust and self-confidence, separation anxiety, and bedtime battles. Common worries of parents and ways of helping a baby grow emotionally are important here:

No one is perfect, no one can do all they'd like to do for their baby. But if you are able to love your baby and show her that you value her, whether she's crying or smiling, you've given her her first chance to be loved. If she is offered this first important experience, your baby can love and trust others in the same way (Book IV, p. 19).

The books discuss personality development and concerns with toddlers such as messiness, tantrums, setting limits, rewards and punishments, and taking risks. There is presentation of information to aid parents in understanding these behaviors:

Tantrums are so upsetting--to the parents and the child. However much she screams "No" or "Shan't" or "Go away", a child's tantrum is always a cry for help. The basic message is "I can't understand or cope with this awful feeling I've got inside me" (Book VII, P. 18).

There is discussion of children's fears, the need for security, and the toddler's struggle of dependence/independence. The books include guidelines to assist parents in these aspects of child rearing:

Children need kindly encouragement to do things for themselves, but at the same time they shouldn't have to feel that there's nobody else to rely on. We need to be able to respect both sides of a child --the side which is well up to the limits of what he can achieve at his age and the side which is still a 
baby. To force him or hold him back are equally damaging to his confidence (Book VIII, p. 21).

The books stress cuddles and other kinds of physical and emotional closeness; they advise parents of the importance of this to their child's growth and development.

Development of the child's senses and thought processes is dealt with thoroughly. Specific topics include skills of the newborn, patterns of sleep, the growth of understanding, experimentation, and self-discovery. What babies can see, why babies cry, and how babies use their hands are aspects of development of the senses. There is an excellent discussion of modeling and imitative behaviors, as well as an explanation of why this is so important:

Children learn a great deal from observing and imitating other children and adults. Imitation helps them learn how to do things, and how it feels to be someone else. In the first year imitation consists mainly of direct copying. But during the second year imitation begins to involve memory and imagination too (Book VII, p. 10).

The books describe age-appropriate toys for children less than two and emphasize the importance of books for babies:

The books you read to them add to their own stories to make sense of a world which moves rapidly between reality and imagination. Books extend the sheer enjoyment of imagining things and show them ways in which an imaginary and a real world can safely overlap (Book VIII, p. 7).

Language and social development is the last major subheading under development of the baby. Language development includes such issues as babbling, first words, imitation of others' speech, and talking. Parents are advised that 
children develop at different rates, but age-appropriate behaviors are listed along with developmental norms:

There are large individual differences in the age at which children begin to learn words. and in the speed at which they learn them. Quite a number of children do not start speaking until they are well into their second year. Some even later. Albert Einstein was a late starter and was well into his third year before he could speak (Book VI, P. 9).

This advice may seem rather extreme because not talking by age three is nearly always indicative of a problem. Fortunately, testing is done at all the baby clinics and parents are encouraged to talk with their doctors about any worries and to seek help if it is indicated:

Vision, hearing, and movement tests are all part of the regular check-up offered by baby clinics. When you.visit the clinic, always say if there's anything that worries you. You know your baby best. If the reassurances don't allay your worries, you can always ask to see a specialist. It could well be important. . The sooner any possible defect is noticed, the better for your baby (Book IV, p. 12).

The topic of social development concerns interaction of the baby with other persons. A good explanation of the phenomenon of jealousy between children includes an exercise to help understand this concept and learn how to deal with it. The books address various family issues and discuss play and social interaction with persons outside the family.

An overview of this basic theme--development of the baby--suggests that few topics are neglected. The First Years of Life offers a comprehensive view of physical, emotional, and mental development. The books point out common problems, discuss developmental norms, and present exercises 
to aid in understanding the complexities of growing up from birth to two years of age.

\section{Parenthood}

The second basic focus of The First Years of Life is that of parenthood. This includes health of the parents, parents' relationship, parent-child relations, and social services concerned with child rearing.

The primary concern with parents' health is the physical health of the mother during pregnancy; there is discussion of labor, delivery, and postnatal concerns. The books offer a detailed explanation of pregnancy and there is a multitude of accompanying colored pictures. Signs of pregnancy, pregnancy tests, miscarriages, effects of drugs and smoking on the fetus, and breast/bottle feeding are important aspects of parents' health. Much information is provided about labor and giving birth; the books also include information on inductions and Caesarian sections.

Another important topic under parents' health is that of life changes when the baby comes, along with possible problems. A description of these concerns follows:

Especially if this is her first baby, the mother may feel that her 1 ife has been turned upside down. From a relatively orderly and familiar routine, she is plunged, after birth, into 24-hour a day baby care (and few babies in the early weeks know what "routine" means). All this comes on top of the pregnancy and the emotionally and physically exhausting experience of birth. Al though some women sail through this period without ever feeling it's too much, most feel some degree of exhaustion, temporary inability to cope, or depression. It is important 
for the new mother to realize these reactions are common ones and to seek the support she needs (Book II , p. 28).

The parents' relationship is another major topic discussed in the books. They discuss preparation for childbirth and strongly recommend participation of both parents in the preparation stage. There are considerations of the effects of a new baby on a family, as well as expected life changes:

Many men and women who have managed to adapt quite happily to their roles as halves of a couple may find themselves in disagreement about their roles as parents. And others may realise for the first time when they have their first baby that they have different ideas about how men and women should behave (Book IV, p. 24).

The First Years of Life discusses marital disagreements and their effect on the family. There is much stress on the emotional aspects of the marital relationship, as well as parental roles. This focus is seen as vitally important. There are two exceptional articles on roles and necessary adaptations to a new baby. One of these deals with grandparents, parents, and children and the other concerns itself with roles of husband/father and wife/mother:

Being a husband or wife is a role shared between people of one generation, but being a father or mother means a role shared with two generations - . having to relate two ways means there is room for uncertainty and confusion.. These difficulties are common after the arrival of a new baby and they may go on for some time. As you settle down with the baby you should make time to discuss and do things together as husband and wife (Book IV, p. 25). 
Parent-child relations is the next area of exploration. The books give much attention to the reality of a new baby and the subsequent effects on the family members:

The vital thing to remember is that parenthood has to be learned and that learning can be much more difficult than you expect. Parents need to accept reality: a baby is both nasty and lovely, a screaming horror and an adorable angel. In other words, human and demanding, like any adult (Book III, p. 17 ).

Specific issues include learning to love the baby, cuddles, feeding and sleep patterns, protection of the baby, and breast-feeding. There are articles about bedtime battles, rewards and punishments, tears and tantrums. There is even definite advice about ways of dealing with children's tantrums :

It is important that his feelings do not swamp us. The child needs the reassurance that we can accept his bad feelings without "falling apart" in the way he does. We need to stay in control; but not by denying his feelings (Book VII, p. 18).

The books mention the effect of a new baby on other children as well as toilet training and the baby's development of independence. There is an entire article devoted to concerns of the working mother:

There is a world of difference between being deprived of a mother (or alternative mother-figure) for long periods of time--for example children in institutions or long-stay hospitals; and being separated from the mother for part of each day (Book V, p. 28).

Finally, The First Years of Life discusses the services available for babies, parents, and expectant parents. Some of the issues include the advantages and disadvantages 
of home and hospital deliveries; community support systems are outlined, services are emphasized, and suggestions are offered:

Our ability to cope with demands of daily living depends on many things--our past experiences, our attitudes and expectations, our inventiveness and imagination. It depends, too, on knowing about and making use of the sources of help available in our communities--and our own initiative in creating channels of help where none exist (Book II, p. 3).

There is a study of prenatal concerns and a list of questions often asked at prenatal clinics. There is a thorough examination of preparation for childbirth and an extensive explanation of reasons for childbirth preparation:

Aims of preparing for childbirth

A To build up a woman's confidence in herself so that childbirth can be a satisfying experience

B To give knowledge about pregnancy, labour, and birth

C To help a pregnant woman understand her own reactions to the experience of pregnancy, labour, and childbirth

D To be physically prepared for childbirth

E To provide a setting in which pregnant women can discuss their problems

$F$ To prepare women for the physical and emotional care of the baby (Book II, p. 26).

The National Childbirth Trust is explained. This

British organization focuses upon parent education. Its activities include prenatal classes, promotion of breastfeeding, postnatal support, and provision of information for expectant parents:

The National Childbirth Trust (NCT) is a registered charity.. (which) exists to educate people for parenthood. The NCT was founded in 1956 to improve women's knowledge about childbirth and to help them prepare physically and mentally for this important event (Book: II, p. 31). 
The books discuss baby clinics. In Great Britain, emphasis is on well-child care from birth to age five. Physical, emotional, and social functioning of the child are primary concerns for the baby clinics which are run by the government. The review of social services includes child-care alternatives, immunizations, baby-sitters, and Mothers and Toddlers Clubs.

The First Years of Life deals with a myriad of concerns about parenthood and baby development. It is easy to read and quite coherent; the exercises and questionnaires are very sensible and well-founded. The information on pregnancy and birth is detailed and logical; it undoubtedly allays many fears of the unknown so common to expectant párents.

The course is a step-by-step exercise in tracing a baby's development from the day of conception through the second birthday. It deals with common, everyday problems faced by virtually all parents and it offers an in-depth understanding of child rearing. Emotional aspects of parenthood and baby development are highlighted; this element is so often neglected in dealing with new parents and is vitally important.

One statement which seems indicative of the nature of the course is presented here:

Children vary naturally in what they can do and what they're interested in. This variation is partly inbuilt: bodies "mature" at different ages. But it's also due to the different opportunities individual 
children have to try out their skills, and the encouragement that they are given to do so (Book VII p. 16).

The First Years of Life is nonmoralistic and nonsexist. It is addressed to both parents and seems to make few assumptions about "appropriate" sex-role behaviors in child rearing. Fundamental aspects of baby development and parenthood are considered; some in great depth, some rather superficially. The exercises and questionnaires are excellent tools for increasing understanding.

An article in Social Casework has a coherent definition of parent education which describes the aim of The First Years of Life:

(Parent education) is to provide a basic rudimentary education in child development along with some guidelines for recognizing what behavior is normal and what is cause for concern . . encourage parents to work on their relationships with their children at a crucial developmental period (Atkeson \& Guttentag 1975, p. 519).

There is at least one negative aspect of The First Years of Life which ought to be mentioned here. The books, and undoubtedly the entire course, seem to be directed at a middle-class population; the books also appear to be designed for two-parent families. Some adaptations would be necessary for these books to effectively help one-parent families and those who are not middle class. 
A COMPARISON OF "THE FIRST YEARS OF LIFE"

AND SOME ASPECTS OF PRENATAL AND

PARENT EDUCATION IN AMERICA

The American parents today are worried and uncertain about how to bring up their children. They feel unclear about the proper balance between permissiveness and firmness. They feel they are neglecting their children, yet sometimes resent the demands children make. Americans are unable to define what a good job is. In droves, they seek expert advice. And many prospective parents wonder whether they ought to have children at all (Keniston 1977, p. 3).

As noted from the above statement made by members of The Carnegie Council on Children in 1972, parenting in America holds not only heavy responsibility for the parent, but also malaise and a sense of guilt for those responsible for child rearing. The high incidence of working mothers (in 1970, 40 percent of American mothers worked), the change in family structure, parental role changes, disappearance of the extended family, and the high incidence of single parents have all wrought dramatic changes in the family and in the ways parenting takes place.

Americans have reacted to these rapid changes with anxiety and increased discomfort. Some writers attribute this reaction to the outmoded set of views (Keniston 1977, p. 4) Americans hold about how families function. Although there are differing opinions, most experts in childhood education and parenting seem to share the basic assumption that parents alone ate responsible for the outcome of their 
children. This commonly held concept springs from the assumption that problems of individuals are best treated by changing the individuals who have the problems (Keniston 1977; p. 9). This is further amplified by another assumption which implies that families are autonomous and independent, and anything less than this places them in an "inadequate" category. This notion of self-sufficiency arose from the heritage of early America, built on the concept of rugged individualism. As Keniston notes (1977, p. 9), the Revolution had a psychological impact that established the myth of family independence and self-sufficiency and defined the qualities of the new democratic man in America. During the nineteenth century this doctrine of self-sufficiency came to be applied to the family as well as to individuals; and presently this myth of self-sufficiency permeates the functioning of the American family (Keniston 1977, p. 11). It is important to recognize that family self-sufficiency is indeed a myth and that all of today's families need help in raising children (Keniston 1977, p. 23).

of hundreds of social agencies found in the metropolitan area of Portland, Oregon (Clackamas, Multnomah, and Washington counties), it was found that ninety-two agencies offer some services for parenting to individuals interested in help with prenatal, birth, and parenting care. Included in the agencies are hospitals and schools. Not included are the numerous individuals who also offer prenatal and 
parenting services in relation to their profession or occupation, specifically: teachers, nurses, physicians, psychiatrists, social workers, and ministers. Contact was initiated with a number of these agencies requesting information regarding prenatal care and parenting classes.

It was discovered that although many services were available relative to our requests, the fragmentation of services was immediately obvious. It was discouraging and frustrating to seek specific services and not receive information pertinent to the request. Frequently the agencies provide some part of a parent education program or cooperate with other agencies in delivering services directed to specific needs.

The confusion in determining where to call or whom to ask is compounded when agencies require specific qualifications pertaining to economic status and/or location of residence. The obvious lack of comprehensive information and disjointed services made it difficult to determine what services are available, or where they are located.

Schools and universities in the area were found to provide educational information through classes peculiar to parenting and child development. Again, it was noted that the courses are fragmented and specific information is hidden in a wide array of classes in a wider array of subject material. 
Information pertinent to prenatal and infant care was found to be available through some of the National Service organizations, specifically, The American Red Cross, The International Prepared Child Birth Association, and the Y.W.C.A. These organizations provide information and classes pertaining to preparation. for parenthood and infant care. A good selection of informative material is available with a few booklets of merit provided by the United States Department of Health, Education, and Welfare. Much descriptive material was made available by manufacturers of baby formula, baby food, and supplies. Other pertinent information regarding personal care, nutrition, and health care is provided under the auspices of the American Medical Association, American Dental Association, and the National Dairy As sociation.

The various hospitals in the area provide prenatal and postpartum classes which are sometimes available only to those using the hospital facilities for delivery. However, some of these classes are open to anyone interested for a very small fee. They are usually held in the hospital during the day or in some cases in centers and other places about the city when the demand is sufficient. Word of mouth, or physicians and agency referral, are the usual means of publicity regarding these classes. The classes in the hospital environment are taught by nurses with the emphasis on the biological and physical needs of mother and 
child. Visual aids, tapes, and discussion are the usual format of these very brief, concise sessions.

High schools in the area were found to have a variety of classes pertaining to biological functions, marriage and the family, and child development. The emphasis in most classes is on biological aspects and health education. Several schools have initiated child development classes, however, with students actively studying and working with small children. Most of these classes are elective with the exception of the health education classes which deal with biological aspects, relationships, and money matters. There are no required high school classes in the Portland area dealing with family. life education or parenting. Most of these classes cannot be taken until the eleventh grade when the student is usually seventeen years of age, too late for the many students who have dropped out prior to this time.

Colleges offer classes in child development and marriage. Some of these classes deal with psychological development in parenting; but most of these are offered only to registered students and are not easily available to the general public. Fees, in these situations, are relatively high and the classes are held during the regular school hours which makes it difficult for working parents to attend. Special programs, though limited in.scope, are offered by the counties through the Health Department. These services focus mainly on prenatal and early childhood care. 
Specific concern has been to reach expectant and very young parents. Eligibility is determined by proof of residence in the county and fees are assessed on a sliding-scale basis. Many of the participants are referred by the Department of Human Resources Children's Services Division or by the courts. Prenatal classes are offered for persons with limited financial means or "at risk," usually young women on Aid to Dependent Children.

The counties also offer well-child care clinics which are held in many locations throughout the counties. These clinics provide individual and group counseling with some discussion groups. Newborn clinics also offer some group classes; and in cases where there is pathology, home visits may be made. Specialists in child development and nurses are available for assistance to these families. Although a sliding-scale fee basis is utilized, services are not denied to anyone because of inability to pay.

The federal government has contributed to programs in parent training and counseling for parents of developmentally disabled children throughout the state. National and state goals are listed and services are provided at mental heal th centers and public school districts. State services for needy familes and their children as well as for disabled parents and children are covered by these programs and are provided throughout the state, with the counties acting as the providers. These services are purchased by the county 
agencies of the Children's Services Division with funds provided by the general government under Title $X X$.

With the numerous varieties of programs, times they are taught, where they can be found, and the frequency of the programs, it is extremely difficult to know who has been reached or the number of families and parents needing services or educational information who are left out. Our contacts with the agencies, schools, and hospitals lead us to conclude subjectively that little or no publicity and poor public relations, as well as lack of unity and cohesiveness, have resulted in a serious gap in services delivered to parents and expectant parents. The content of most of the classes and programs appears to emphasize the nutritional and physical needs of mother and child. The emotional and mental needs seem to be poorly met. It is felt that the materials found in "The First Years of Life" provide a thoroughly comprehensive picture of the most important mental, physical, and emotional aspects of the child from conception through the first two years and of the role of the parents during this period.

The vast number of programs in America seem to be directed to middle-class parents except in cases where classes are provided for welfare recipients or teenage girls who are pregnant. This is in direct contrast to the British program which reflects the belief in a continuing need for all parents to better understand themselves and their offspring. 
"The First Years of Life" incorporates the basic issues of physiology and mental growth with a scholastic approach to mental, moral, and physical growth for the human being.

Our analysis has been limited by not having access to the accompanying discussions as presented on British Broadcasting Corporation ( $B B C$ ) radio and television. However, after careful study of the written text and hearing the records provided, we found the materials presented in "The First Years of Life" easily understood and the coverage of major issues and questions pertaining to prenatal care and parenting in the first two years accurate and exhaustive.

We found that a plethora of information exists in the United States regarding prenatal care, birth, and parenting. We also found that there is much fragmentation, overlapping, and gaps in the way services and programs are delivered. The numerous agencies, clinics, and hospitals that provide these services offer some part of information which is available in "The First Years of Life." The focus in the American agencies, however, seems to be mainly on the physical and medical aspects of parenting and child care. Emotional and psychological aspects are largely neglected. Many programs are categorical rather than comprehensive in nature. Although this is necessary for specific problems, the consequences in many instances leads to poor 
coordination. Most services are designed to treat problems, not to prevent them.

It has also become clear that there is a lack of coordination and continuity in the programs which provide services and education for prenatal care and parenting education. There is a great need for ways to provide services of this kind for everyone, whatever their income, wherever they live, continuously and comprehensively. There is also a crucial need for professional educators who can help parents learn how to educate their children (White 1977, p. 246). White states that many people who are now in the field of parenting education are inadequately trained for the task. Only recently have we realized the importance of education during infancy as well as the need for good prenatal care.

With the information we now have regarding these important factors, it is felt that the professional social worker could offer a valuable service in the area of parenting education. Professional social workers have been trained to understand the psychological and social forces involved in family living. Their training also includes knowledge about the developmental process of the human being.

In order to bring about a more effective program of parent education and related services to all who are interested, a background in the social, psychological, and developmental aspects of human life seems essential. The 
professional social worker could provide a valuable force in this area. 


\section{CHAPTER V \\ CONCLUSIONS AND RECOMMENDATIONS}

ISSUES

The primary data base is a British parent education course; this is analyzed as it compares with specific aspects of the American system of parent education. Our underlying philosophy is that increased knowledge may enhance effective parenting. No data uncovered in this study indicated otherwise. Our conclusions are based on various issues which emerged.

Parent education is a first step in the prevention of child abuse, neglect, and otherwise inadequate parenting. Parenting is not merely an.instinctive skill that some are born with; it is also a learned behavior which is developed through education and experience. In our mobile society the extended family seldom provides training or emotional support in child rearing.

There is a sense of confusion about how to raise children in this country. Expectations and pressures to produce offspring continue to exist; however, there is a definite lack of education and planned parenthood.

It is realized that no one way exists to raise children. "The first Years of Life" course recognizes a variety 
of parenting styles. Recognition of the uniqueness of each child assists in limiting the competitive nature of child rearing and the resulting anxiety when comparing one's child to another. The reassurance that is an integral part of "The First Years of Life" is one of the dominant elements of this: series.

A focus on the expected or newborn child is common when discussing childbirth. The birth of a child is recognized as a family crisis situation; therefore, more emphasis is needed on the physical and emotional health of the parents. The pressures of time and money, coupled with the changes in life style and roles, provide occasion for breakdown in the family's functioning. Some tasks of parent education are to help parents become aware of the changes in their lives; to facilitate the exploration of feelings regarding the situation; to promote proper diet and exercise; and to support the harmony and unity of strong marital and familial relationships. Confidence and self-esteem enable the parents to tackle their tasks more effectively. "The First Years of Life" emphasizes these factors.

Parent participation in activities with their children is another element of sound child-rearing practices. Playing, singing, working, and reading are four such activities. 


\section{RECOMMENDATI ONS}

On the basis of our research study we make the following subjective recommendations. In parent education openness or motivation for learning is not always present. Therefore, in educating parents one must recognize that repetition is an important element of learning. Frequent review of the information rather than a one-time crash course may result in the development of better parenting skills.

Discussion groups have been. shown to be valued and desired in parent education. Class and cultural difference must also be recognized in the establishment of new parenting programs or the reorganization of established parenting programs. Programming must be flexible to allow for different child-rearing techniques.

Parenting programs should emphasize activities that families can do together, as a group, which enhance family functioning. Activities are to be planned with the attitude that babies are participants, not just recipients. Emotional and physical support for parents should be a primary objective, not merely an afterthought.

A great deal of emphasis has been placed on programs for mothers. The obvious lack of fathers as participants in parenting programs, coupled with research findings, suggest that fathers should be equally involved in parent education. It is a reality in the United States that the tasks and 
roles of "motherhood" must be shared in many family situations. Emotional and cognitive preparation for parenthood should be equally addressed to males and females throughout their lives.

The unification of medical, educational, and social services is imperative for effective parent education. At the present time it is difficult for a social worker to comprehend and utilize the available services. Where does this leave the average parent who is seeking help? The multiple levels of funding in this field complicate the coordination of programming for parent education. We recommend that the state of Oregon fund a quantitative and qualitative study of parent education and provide a guide to the available opportunities for the use of its citizens.

It is our subjective opinion that parent education should be available to all parents. It is not enough to provide parenting information and services only for the "at risk" population, and it is mandatory to recognize that parent education must be accessible on a more universal basis.

It is recommended that "The First Years of Life" be adapted for the United States and utilized as a course of study in parent education. On the local level it seems feasible that the course could be presented through the Public Broadcasting Service, or through the continuing education classes at the community colleges. Literature, such as The First Years of Life, that is objective, 
comprehensive, and non-judgmental provides a quality learning base.

\section{SUGGESTED READINGS}

Based on the literature review the following books are recommended for parents to use in their child-rearing practice.

\section{Books for Parents}

Caplan, Frank, Editor: The Parenting Advisor. Garden City, N.Y.: Doubleday, 1977.

Caplan, Frank, Editor. Parents Yellow Pages. Garden City, N.Y.: Doubleday, 1978.

Ginott, Haim. Between Parent and Child. New York: Macmillan \& Co., 1965.

Ilg, Frances L., Ames, Louise Bates. Child Behavior. New York: Harper \& Row, 1955.

Keniston, Kenneth, Carnegie Council on Children. All Our

Children. New York: Harcourt Brace Jovanovich, 1977.

Salk, Lee. What Every Child Would Like His Parent to Know.

New York: David McKay Co., 1972.

Spock, Benjamin. Baby and Child Care. Revised Edition.

New York: Pocket Book, 1968.

The Open University. The First Years of Life. Milton

Keynes, England: The Open University Press, 1977.

(Available from Dr. Frank Miles, School of Social Work, Portland State University.) 
White, Burton. First Years of Life. New York: Avon Books, 1975 .

\section{Books to Read with Children}

Adams, Pam. Illustrator. Old McDonald Had a Farm. Grosset \& Dunlap, 1975 .

Anno, Mitsumasa. Anno's Alphabet. Thomas Y. Crowel1, Co., 1973.

Anno, Mitsumasa. Anno's Counting Book. Thomas Y. Crowell, Co., 1975 .

Lionni, Leo. Little Yellow \& Little Blue. Ivan obolmsky, Inc., 1959 .

Mayer, Mercer. The Great Cat Chase. Four Winds Press, 1974 .

Nakatami, Chiyoko. My Teddy Bear. Thomas Y. Crowell, Co., 1975 .

Peppe, Rodney. Odd One Out. Viking Press, 1974. Peppé, Rodney. Humpty Dumpty. Viking Press, 1975. Sendak, Maurice. Where the Wild Things Are. Harper \& Row, 1963.

Spier, Peter. Crash! Bang! Boom! Doubleday, 1972. Brian Wildsmith's Mother Goose. Franklin Watts, Inc., 1964. 
WORKS CONSULTED 
WORKS CONSULTED

Adams, M. E. "A Supplement on Parentcraft: Providing a Service." Nursing Mirror 145 (29 September 1977): xi $i-x i i i$.

Aries, Philippe. Centuries of Childhood. New York: Vintage Books, 1962 .

Ashton, R. M. "A Supplement on Parentcraft: The Parentcraft Teacher." Nursing Mirror 145 (29 September $1977): x v$.

Atkeson, Paula and Guttentag, Merna. "A Parent Discussion Group in a Nursery School." Social Casework 56 (November 1975):515-520.

Bane, Mary Jo. "A Review of Child Care Books." Harvard Educational Review 43 (November 1973):669-680.

Beebe, E. Rick. "Expectant Parent Classes: A Case Study." The Family Coordinator 27 (January 1978):55-58.

Bigner, Jerry. "Parent Education in Popular Literature: 1950-1970." The Family Coordinator 21 (July 1972): $313-319$.

Boll, T. J.; Dimino, E.; and Mattsson, A. E. "Parenting Attitudes: The Role of Personality Style and Childhood Long-term Illness." Journal of Psychosomatic Research 22 (1978):209-213.

Boston Children's Medical Center. Pregnancy, Birth, and the Newborn Baby. New York: Delacorte Press, 1972.

Boulette, Teresa R. "Parenting: Special Needs of Lowincome Spanish Surnamed Families." Pediatric Annals 6 (September 1977):613-619.

Brazelton, T. Berry. "Reaching Out to New Parents." Children Today 7 (July-August 1978):27.

"Britain's Open University." The Center Magazine, September-October 1978, pp. 7-20. 
Brown, Bruce W. "Parents' Discipline of Children in Public Places." The Family Coordinator 28 (January 1979): $67-71$.

Brown, Marie Scott and Hurlock, Joan T. "Mothering the Mother." American Journal of Nursing 77 (March 1977): 439-441.

Bruce, John A. "Adolescent Parents: A Special Case of the Unplanned Family." The Family Coordinator 27 (January $1978): 75-76$.

Buckland, Clare M. "Toward a Theory of Parent Education: Family Learning Centers in the Post-industrial Society." The Family Coordinator 21 (April 1972):151-162.

Caplan, Frank, ed. The First Twelve Months of Life: Your Baby's Growth Month by Month. New York: Grosset and Dunlap, 1973.

- The Parenting Advisor. Garden City, N.Y.: Doubleday/Anchor Press, 1977.

- Parents Yellow Pages. Garden City, N.Y.:

Doubleday/Anchor Press, 1978.

Caplan, Frank and Theresa. The Second Twelve Months of Life--A Kaleidescope of Growth. New York: Grosset and Dunlap, 1977.

Chamberlain, Robert W. "Parenting Styles, Child Behavior, and the Pediatrician." Pediatric Annals 6 (September $1977): 584-591$.

Channels, Vera. "Family Life Education through the Use of Novels." The Family Coordinator 20 (July 1971): $225-230$.

Charnley, Lucile and Myre, Gloria. "Parent-Infant Education." Children Today 6 (March-April 1977):18-21.

Chute, Deborah. "Creating a Learning Environment." Canadian Nurse 74 (January 1978):48-51.

Clayton, Patricia N. "Meeting the Needs of the Single Parent Family." The Family Coordinator 20 (October 1971): $327-336$.

Coley, Silas B., Jr. "Delivery: A Trauma for Fathers?" The Family Coordinator 25 (October 1976):359-363. 
Croake, James W. and Glover, Kenneth E. "A History and Evaluation of Parent Education." The Family Coordinator 26 (Apri] 1977):151-157.

Cromwell, Ronald E. and Gangel, Joan L. "A Social 'Action' Program Directed to Single Pregnant Girls and Adolescent Parents." The Family Coordinator 23 (January $1974): 61-72$.

Crosby, John F. "The Effect of Family Life Education on the Values and Attitudes of Adolescents." The Family Coordinator 20 (April 1971):137-140.

Daly, Ronald T. and Reeves, John P. "The Use of Human Interaction Laboratories in Family Life Courses." The Family Coordinator 22 (October 1973):413-418.

D'Augelli, Judith Frankel and Werner, Joan M. "Training Parents as Mental Heal th Agents." Community Mental Health Journal 14 (Spring 1978):14-25.

de Frain, John D. "Sexism in Parenting Manuals." The FamiIy Coordinator 26 (July 1977):245-251.

de Lissovoy, Vladimar. "Comments on 'The Keeping Fathers of America.'" The Family Coordinator 25 (October 1976):393-395.

Dodson, Fitzhugh. How to Parent. New York: Signet Books, 1971 .

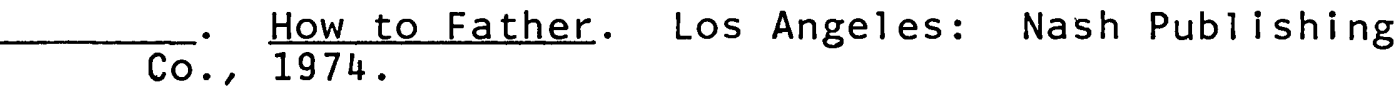

Dreikurs, Rudolf. Children: The Challenge. New York: Hawthorn Books, 1964 .

Faber, Adele and Mazlish, Elaine. Liberated Parents, Liberated Children. New York: Grosset and Dunlap, 1974.

Fein, Edith. "Motivating Attendance in Parent Education Groups." Social Work 17 (July 1972):105-107.

Fein, Robert A. "Men's Entrance to Parenthood." The Family Coordinator 25 (October 1976):341-347.

Fohlin, Mary Bercovitz. "Selection and Training of Teachers for Family Life Education Programs." The Family Coordinator 20 (July 1971):231-242. 
Friedman, Alma S. and David B. "Parenting: A Developmental Process." Pediatric Annals 6 (September 1977):

$564-572$.

Gesel1, Arnold; Ilg, Frances L.; and Ames, Louise Bates. Infant and Child in the Culture of Today. Revised edition. New York: Harper and Row, 1974.

Ginott, Haim. Between Parent and Child. New York: Macmillan and Co., 1965.

Gladding, S. T. "Empathy, Gender, and Training as Factors in the Identification of Normal Infant-cry Signals." Perceptual and Motor Skills 47 (August 1978):267-270.

Goodman, Earl O., Jr. "Modeling: A Method of Parent Education." The Family Coordinator 24 (January 1975):7-12.

Gordon, Ira J. The Infant Experience. Columbus, Ohio: Charles E. Merrill Publishing Co., 1975.

Gordon, Thomas. Parent Effectiveness Training. New York: New American Library, 1970.

Gross, Beatrice and Ronald. "Parent-Child Development Centers: Creating Models for Parent Education." Children Today 6 (November-December 1977):18-22.

Guerney, Bernard G., Jr.; Guerney, Louise F.; and Stove, Lillian. "Facilitative Therapist Attitudes in Training Parents as Psychotherapeutic Agents." The Family Coordinator 21 (July 1972):275-278.

Harrison-Ross, Phyllis. "Parenting the Black Child." Pediatric Annals 6 (September 19.77):605-612.

Hennessey, Deborah; Holgate, Becky; and Marr, June. "With a Little Help from My Friends." Nursing Times 74 (13 April 1978):103-106.

Honig, Alice S. "What We Need to know to Help the Teenage Parent." The Family Coordinator 27 (April 1978):

$113-120$.

Hrobsky, Diane M. "Transition to Parenthood." Nursing Clinics of North America 12 (September 1977):457-468.

Huber, Herman and Lynch, Frank. "Teaching Behavioral Skills to Parents: A Preventive Role for Mental Health."

Children Today 7 (January-February 1978):8-10. 
Hughes, Cynthia Bach. "An Eclectic Approach to Parent Group Education." Nursing Clinics of North America 12

(September 1977):469-479.

Hurwitz, A. "Child Abuse: A Program for Intervention." Nursing Outlook 25 (September 1977):575-577.

Ilfield, Frederick W., Jr. "Current Social Stressors and Symptoms of Depression." American Journal of Psychiatry 134 (February 1977): 161-166.

Ilg, Frances L. and Ames, Louise Bates. Child Behavior. New York: Harper and Row, 1955.

Johnson, Colleen Leahy and Arvid, Frank. "Attitudes toward Parenting in Dual Career Families." American Journal of Psychiatry 134 (April 1977):395-396.

Johnston, Maxine; Kayne, Martha; and Mittleider, Kathy. "Putting More Pep in Parenting." American Journal of Nursing 77 (June 1977):994-995.

Kagan, Jerome. "The Parental Love Trap." Psychology Today, August 1978, pp. 54-61, 91.

Keniston, Kenneth and The Carneigie Council on Children. All Our Children. New York: Harcourt Brace Jovanovich, 1977.

Kerckhoff, Florence G.; Ulmschneider, Ann; and Adams, Connie. "College and University Programs in Parent Education." The Family Coordinator 25 (April 1976): 131-133.

Kerckhoff, Richard K. and Habig, Myrna. "Parent Education as Provided by Secondary Schools." The Family Coordinator 25 (April 1976):127-130.

Kerckhoff, Richard K. and The Family Coordinator Family Life Education Panel. "Commercial Teaching Materials Used in High School Family Life Courses." The Family Coordinator 22 (July 1973):275-284.

Lamb, Michael E. and Janie E. "The Nature and Importance of the Father-Infant Relationship." The Family Coordinator 25 (October 1976):379-385.

Lebow, Michal D. "The Behavior Mod Process for Parent-Child Therapy." The Family Coordinator 22 (July 1973):

$313-320$. 
LeShan, Eda. How Do Your Children Grow? New York: David McKay, Co., Inc., 1971.

Levin, Elaine. "Development of a Family Education Program in a Community Social Service Agency." The Family Coordinator 24 (July 1975):343-350.

Luckey, Eleanore Braun. "Family Life Education Revisited." The Family Coordinator 27 (January 1978):69-73.

Maxwell, Joseph W. "The Keeping Father of America." The Family Coordinator 25 (October 1976):387-392.

McClelland, David C.; Constantian, Carol A.; Regalado, David; and Stone, Carolyn. "Making It to Maturity." Psychology Today, June 1978, pp. 42-52, 114.

McKeel, Nancy Lynn. "Child Abuse Can Be Prevented." American Journal of Nursing 78 (September 1978):1478-1482.

Miller, Christina. "Working with Parents of High Risk Infants." American Journal of Nursing 78 (July 1978): $1228-1230$.

Mitchell, Jeananne and McManis, Donald L. "Effects of P.E.T. on Authoritarian Attitudes toward Child-rearing in Parents and Non-parents." Psychological Reports 41 (August 1977):215-218.

Mitchel1, Robert McNair and Klein, Ted. Nine Months to Go. New York: Ace Books, 1960.

Moerk, Ernest and Becker, Penelope. "Attitudes of High School Students toward Future Marriage and College Education." The Family Coordinator 20 (January 1971): 67-73.

Morris, Anne G. "Parent Education in Well-baby Care: A New Role for the Occupational Therapist." American Journal of Occupational Therapy 32 (February 1978): 75-76.

Nichols, Beverly. "Motherhood, Mothering, and Casework." Social Casework 58 (January 1977):29-35.

Parke, Ross D. and Sarwin, Douglas B. "The Father's Role in Infancy: A Re-evaluation." The Family Coordinator 25 (October 1976):365-371.

Patterson, Gerald. Families. Champaign, IL: Research Press, Inc., 1971. 
Penn, John V. "A Model for Training Foster Parents in Behavior Modification Techniques." Child Welfare 57 (March 1978):175-180.

Piers, Maria W. Growing up with Children. Chicago: Quadrangle Books, 1966.

Pitcairn, Lenora. "Parents of the Future." Midwife, Health visitor, and Community Nurse 14 (November 1978): $386-388$.

Polansky, Norma A. and Williams, David P. "Class Orientations to Child Neglect." Social Work 23 (September $1978): 397-401$.

Pomeranz, Virginia E. and Schultz, Dodi. The First Five Years. Garden City, N.Y.: Doubleday and Co., 1973.

Portnoi, Tikvak S.; Bojrab, Darlene; and Ohringer, Robin. "Stop the Action: A Program for Parents of Severely Disturbed Children." Health and Social Work 3 (May 1978) : 135-156.

Price-Bonham, Sharon and Skeen, Patty. "A Comparison of Black and White Fathers for Parent Education." The Family Coordinator 28 (January 1979):53-59.

Reinhart, John B. "Syndromes of Deficits in Parenting." Pediatric Annals 6 (October 1977):628-635.

Rendina, Irma and Dickerscheid, Jean D. "Father Involvement with First-born Infants." The Family Coordinator 25 (October 1976):373-378.

Renz, Laurie and Cohen, Mikal. "Interpersonal Skill Practice as a Component in Effective Parent Training." Community Mental Health Journal 13 (Spring 1977): 54-57.

Rypma, Craig B. "The Biological Bases of the Paternal Responses." The Family Coordinator 25 (October 1976): $335-340$.

Salk, Lee. What Every Child Would Like His Parent to Know. New York: David McKay, Co., 1972.

Sandler, Jack; Van Deran, Candy; and Miehoan, Mariann. "Training Child Abusers in the Use of Positive Reinforcement Practices." Behaviour Research and Therapy $16(1978): 169-175$. 
Sands, Rosalind M. "Toward Communal Child Rearing." Social Work 19 (May 1973):55-59.

Scleicher, Isabel M. "Teaching Parents to Cope with Behavior Problems." American Journal of Nursing 78 (May $1978): 838-839$.

Schneiderman, Leonard. "Collaboration between the Health and Social Services in England." Social Work 23 (May 1978) : 192-197.

Skolnick, Arlene. "Myth of the Vulnerable Child." Psychology Today, February 1978, pp. 56-65.

Slater, Philip. Footholds. New York: E. P. Dutton, 1977.

Smoyak, Shirley A. "Symposium on Parenting: Introduction:" Nursing Clinics of North America 12 (September 1977): $447-455$.

Spock, Benjamin. Baby and Child Care. Revised edition. New York: Pocket Books, 1968.

Raising Children in a Difficult Time. New York:

W. W. Norton Co., Inc., 1974 .

Sullivan, Joyce; Gryzlo, Barbara; and Schwartz,William. "Cerification of Family Life Educators: A Status Report of State Departments of Education." The Family Coordinator 27 (July 1978):269-272.

Talbot, Nathan B. Raising Children in Modern America: Problems and Prospective Solutions. Boston: Little, Brown, and Co., 1976.

Raising Children in Modern America: What Parents and Society Should Be Doing for Their Children. Boston: Little, Brown, and Co., 1976.

The Open University. The First Years of Life. 8 vols. Milton Keynes, Great Britain: The Open University Press, 1977.

Thistleton, Kristin Spell. "The Abusive and Neglectful Parent: Treatment through Parent Education." Nursing Clinics of North America 12 (September 1977):513-524.

Turner, S. M. and Juarez, S. P. "Nurses Exchange: Wel1child Care." Pedatric Nursing 4 (March-April 1978): 51-52. 
Turrini, Patsy. "A Mother's Center." Social Work 22 (November 1977):478-483.

U. S. Department of Health, Education, and Welfare. Infant Care. Washington, D.C.: U. S. Government Printing office, 1973 .

- Prenatal Care. Washington, D.C.: U. S. Government Printing office, 1973. U. S. Your child from One to Six. Washington, D.C.:

Walsh, Joseph A. "Dr. Seuss Meets Dr. Freud: Primary Prevention in the Community Library.". American Journal of Public Health 67 (June 1977):561-562.

Watson, J. Allen and Kivett, Vira R. "Influence on the Life Satisfaction of older Fathers." The Family Coordinator 25 (October 1976):462-488.

Weiss, Robert S. "The Contribution of an Organization of Single Parents to the Well-being of Its Members." The Family Coordinator 22 (July 1973):321-326.

Wente, Arel S. and Crockenberg, Susan B. "Transition to Fatherhood: Lamaze Preparation, Adjustment Difficulty, and the Husband-wife Relationship." The Family Coordinator 25 (October 1976):351-363.

Whatley, Alice Elrod. "Graduate Students' Perceptions of Needed Personal Characteristics for Family Life Educators." The Family Coordinator 22 (Apri1 1973): 193-198.

White, Burton. The First Three Years of Life. New York: Avon Books, 1975.

Williams, Janet K. "Learning Needs of New Parents." American Journal of Nursing 77 (July 1977):1173.

Wilson, Ann L. "Parenting in Perspective." Family and Community Health 1 (November 1978):65-77.

Wilson, Harriett. "Parenting in Poverty." British Journal of Social Work 4 (Autumn 1974):241-254.

Young, C. "A Supplement on Parentcraft: The Need for Parentcraft." Nursing Mirror 145 (September 1977): $i, i i$. 
Ziegler, R. G. and Musliner, P. J. "Persistent Themes: A Naturalistic Study of Personality Development in the Family." Family Process 16 (September 1977):293-305. 
APPENDICES 


\section{APPENDIX A}

\section{INDEX FOR "THE FIRST YEARS OF LIFE"}

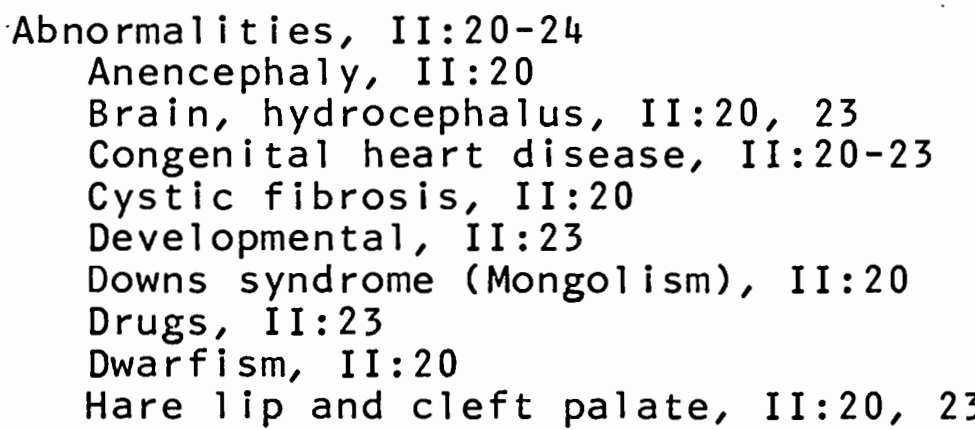

Mental handicap, II: 20

Spine, Spina Bifida, II: 20

Absence from parents, VI:24, 25

Accidents, VI:18, 19

Burns, cuts, VI: 19

Falling, VI: 19

Poisoning, VI:19

Suffocation, VI: 19

Amniotic Sac, I I : 15

Aspirin, I:19

Babbling, $v: 6,7$

Baby-sitters, V:31; VI:29, 30, 31

Birth, I I :6-9

Caesarian, II I : 14-15

Drug free, III: 7

Gas, II I : 8

Induction, I I I : 12

Natura I, I I I $: 13$

Pain free, "epidurals," II I: 8

Blood pressure, in mother, III:13

Books,

For babies, VIII:6-9

For different stages, VIII: 8,9

Picture, VIII: 6

Boredom, in babies, $v: 24,25$

Bottle Feeding, I I: 18, 19

Laxatives, IV: 7

Movements, I $\mathrm{V}: 6$

Sore bottoms, IV: 7

Breast-feeding,.. I I : 18, 19; II I :26, 27 
Caesarian Section, I:26

Operation, I I I:14, 15

Care of newborn, I I I: 23

of new mother, II I:28-29

Cervix, neck, I: 7

Children,

Reaction to new baby, VII:14

Jealous, VII:I5

Clinics, baby, IV:30

Doctor, IV:30

Obstetrician, I I:10, 11

Clitoris, I: 7

Clubs, mother and toddler, VII:3I

Conception, I: 10, 11

Timetables, I: 11

Conflicts, see disagreements: parents and children

Contractions, show, breaking of waters, III:3

Control, of head and sitting by child, IV:17

Control of child, VI:26-27

Understanding, uniqueness of individual, VI:26

Course Instructions, I:3-6

Crisis in parenting, VII:22-25

Crying, causes, IV:8-10, 20

Parents reactions to, IV: 10

Cuddling, v: 8,9

Delivery, I:26, 27

Hospital, I: 27

Home, I : 27

Depression, new mothers, II I $: 29$

Development, expectations, VII:3-5

Disagreements, parents, VII:20-2I

Drugs,

In pregnancy, I : 18, 19

For special conditions, I $: 19$

Egg, see pregnancy

Experimenting, VI I:7-9

Families, pregnant, II $: 8$

Changes in 1 ife style, II: 8

Fallopian tubes, I: 6

Father, as parent, II: 8

Fears, Child

Nightmares, VIII: 24

of hospitals, VI $: 24$

of separation from parents, VI:24, 25

of strangers, VI: 24

other fears, VIII: 25 
Feeding, VI $: 18-23$

And choking, $V: 17$

And growth, $v: 21$

Force feeding, $V: 20$

Obesity in babies, $v: 22-23$

Feeling, as husband role, IV:25, 26 as wife role, VI:25, 26

Feelings, baby's at birth, II I : 16

Feelings, parents, VI: 28 anger, depression, time for self, VI:28

Feelings in pregnancy, II $: 8$

Husband in pregnancy, I I :9

Wife in pregnancy, I I:9

Fertilization, of egg, see pregnancy

Fetus, I I $: 14-15$

Games, IV : 15

Genetic abnormalities, II : 20

Grandparents, VII:16, 17

Grasping, early development, $V: 3,4,5$

Growing up, VIII:20-21

Hospitals, children, VI: 25

Separation from parent, VI:25

Hospitalization,

For delivery of baby, I :26, 27

Kind of, I : 28

Husband and labor, I I I:4

Hymen, I: 7

I l iness, IV:26-29

In hospital, IV:28, 29

Serious, IV: 26

Symptoms, IV: 26

Imitation,

In first year, VII: 10

In second year, VII: 11

Immun izations, $V: 26,27$

Induct ion, I I I : 12, 1.3

Inheritance, I I $: 21$

Genetic abnormalities, I I : 20

Jaundice, I I I : 10

Labor, II I:3-9

Breaking of waters, I I $: 3$

Contractions, I I I: $6,8,9$

Husbands, I I I 4

Induction, I I : 12-13

Show, I I I $: 3$

Stages of, II I: 6, 8,9 
Leboyer, Frederick, II I:16

Love,

Mother, IV: 19

Learning by baby, IV: 20

Mecon i um, I I : 15

Mess and living with it, VIII:14-15

Messy playing materials, VIII: 14

Miscarriages, I: 20-21

Causes of, I: 20-21

Symptoms of, I: 21

Newborns, description of, III:18-28

Birthmarks, I I $: 19$

Ears, flattened, III: 14

Eyes, bloodshot, I I I: 19

Eyes, squinting of, I I I: 18

Genitals, III:20

Hands and feet, II I : 20

Hair, II I : 18

Head, I I $: 18,19$

Lumps on scalp, I I : 18

Scars on head, II I $: 18$

Senses, I I I : 23

Skills of, II I: 21

Skin, II I: 14

Skul1, odd shaped, I I I: 18

Soft spot, II I : 18

Swollen scalp, I I I $: 18$

Teeth, I I I : 18

Tongue, II I : 19

Nurseries, $V: 31$

Baby-sitters, $V: 31$

Obesity, see feeding

Objects in early development, VI:11-15

Ident ification, VI: 12-15

One-year-old's development, VI:16, 17

Ovaries, I: 6

Ovulation, I:10-13

Patterns, sleep, IV:3-5

Living with baby, IV:23

Perineum, I:7

Permissiveness, VII $: 24$

Play, VII:3-5; V:5 


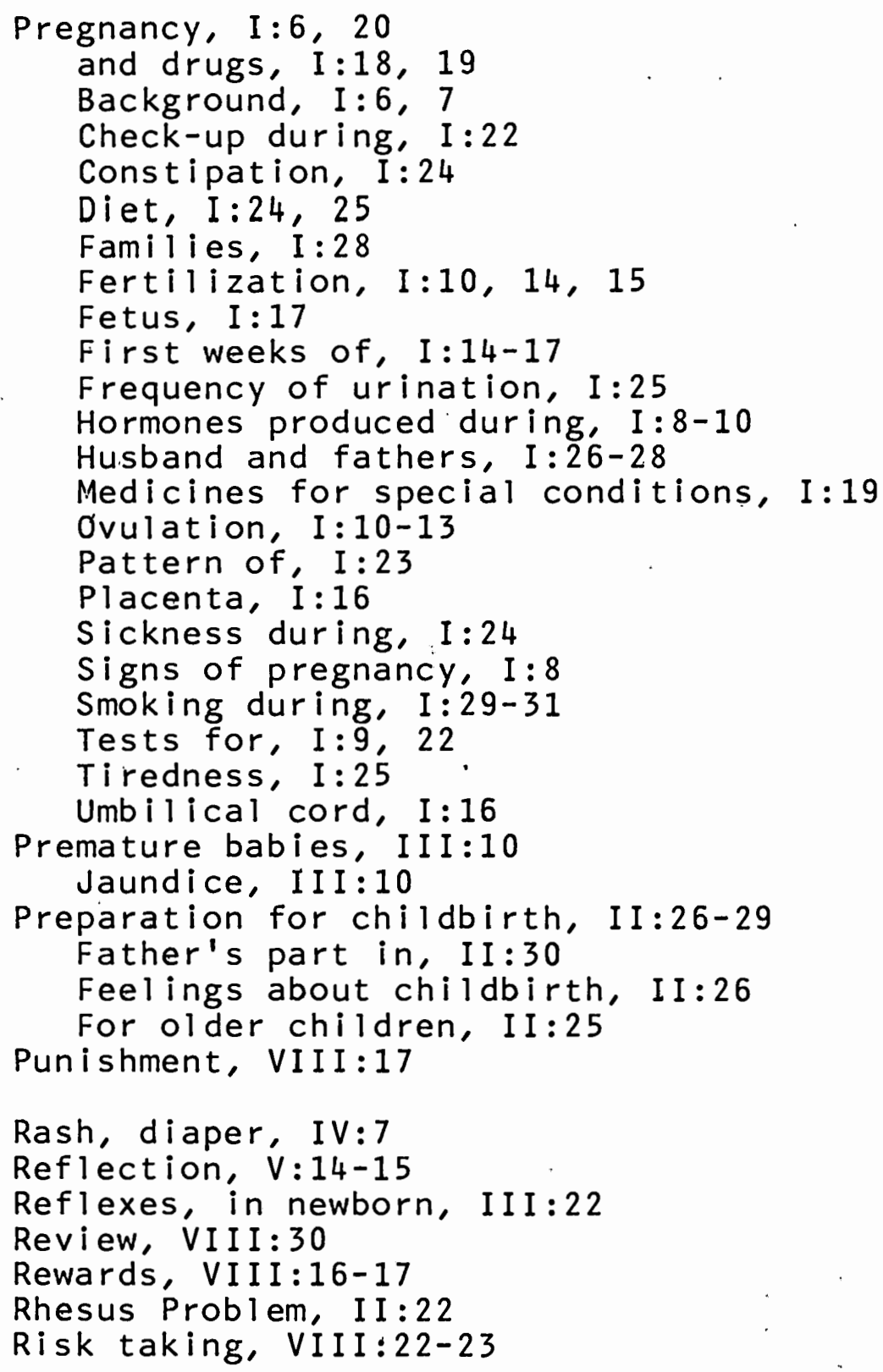

Security, blankets and toys, VII:30

Senses, in newborn, III:23

Setting limits, VII:24-25

Bedtime, VII:28-29

Control, VII:26

Sight, visual choices, IV:11-15

Socializing, VIII:26-29

With other adults, VIII: 28

With other children, VIII:26, 27

Sounds, IV: 16

Spastic baby, I I : 20 
Speech, IV:21-22; VIII : 10-13

Child talk, VIII:12-13

First words, VIII:11-13

Mothers and parents talk, VIII: 13

Spina Bifida, I I: 20

Steps, first, VI:6-7

Support Services, I I : 4

Friends and neighbors, I I : 6

Homemaker service, I I : 5

Voluntary, I I : 4

Welfare, I I: 4

Tantrum, VII $: 18$

Dealing with, VII:19

Tests, special in pregnancy, II $: 24$

Toilet training, VIII:18-19

Readiness, VIII: 18

Toys,

Choosing, VII $: 12-13$

Good person, VII I :28-29

And tools, use of in growth, VI:3-5

Trust, building self-confidence, IV:18-19; VI:20-23

Understanding, $v: 10-13$

Uterus, $I: 6$

Vacation, without child, VI:25

Vagina, I : 6-7

Virus, effect in pregnancy, II:23

Womb, fetal growth, I I:14-15

Breathing, fetal, I I : 17

Changes in pregnancy, I I:1-8, 10

Hearing, I I : 17

Heartbeats, I I : 16

In fertilization, II: $1-6$

Movement, I I : 16

Survival in, I I: 15

Survival out of, II:15

Swal lowing, I I : 16

Urine passing, II:16

$X$-rays, effect in pregnancy, II :23 


\section{APPENDIX B}

\section{GLOSSARY FOR "THE FIRST YEARS OF LIFE"}

\section{English Word/Phrase}

about

Action Man
adventure-playground
apparatus

aeroplane

age-mates

agonising

all-in-all

anaemic

anaes thetic

analyse

antenatal

artful enough to be

aunties

babyminder

bath (verb)

beaker

bear a charmed life

beast 1 y

bed-sitting room
American Translation

around

super-hero, such as Superman

jungle gym; monkey bars.

airplane

peers

agonizing

everything

anemic

anesthetic

analyze

prenatal

capable of being

aunts

baby-sitter

bathe (verb)

glass

lead a lucky life

naughty

furnished room 
English Word/Phrase

behaviour

bellowing

birth wasn't straightforward

biscuit

black treacle

blanc mange

bonny

booking-in-clinic

bowels motions

brick

button thread

"Bye Bye Bunting"

carried on

categorise

cat net

centimetres

centre

change plugs and fuses

chap

chesty illness

childminder

chips

cinema

clear the decks?

\section{American Translation}

behavior

howling

difficult birth

cookie

molasses

custard

pretty; healthy

prenatal clinic

bowel movements

block

heavy-duty thread

"Rock-a-bye Baby"

managed

categorize

mosquito netting

cent imeters

center

child-proof electrical outlets

boy

respiratory illness

baby-sitter; child care worker

french fries

theater

walk away; ignore ( $i t$ ) 
English Word/Phrase

cleft plate

climbing frame

collected

colour

connexions

$\cos$

$\cot$

cot death

cottoned onto the notion

council block

counsellor

creche

crisps

criticising

cut across

dialling

diarrhoea

din

disc (record)

di sorganised

DIY shop

dogged

dozy

draughts

\section{American Translation}

cleft palate

jungle gym

picked up

color.

connections

because

crib; bed

crib death; SIDS (Sudden Infant Death Syndrome)

seemed to decide

public housing project

counselor

nursery

criticizing

interrupt

dialing

diarrhea

noise

record (noun)

disorganized

followed

drowsy

drafts 
99

English Word/Phrase

dummy

early on, then

emphas i sud

enquire

ensure

explicable

extract

faeces

fancies

favour

favourite

feeds (noun)

fertilise

fibres

flannel

flat (noun)

flavour

flex

fl lummox

foetal

foetus

farseeing

footfall
American Translation

pacifier

at first

emphasized

inquire

insure

understandably le

part

feces

wants

favor.

favorite

meals; feedings

fertilize

fibers

washcloth

apartment

flavor

electric cord

confuse; perplex

fetal

fetus

foreseeing

footsteps 
English Word/Phrase

fortnight

fraught

fullstop

GP

gay

get a fright

give scrub

giving tea to teddy

grammes

gran

graze

gripe

grizzle

haemorrhoids

haemophilia

harel ip

have a try (verb)

have got

have not got to...

health visitor

hol iday

honour

\section{American Translation}

two weeks

loaded

period (punctuation mark)

family doctor

happy

be afraid

wash

having a tea party with a teddy bear

grams

grandmo ther

scrape

gas

fuss

hemorrhoids

hemophilia

cleft $1 \mathrm{ip}$

try it

have been

are not yet at...

doctor; public health nurse;

clinic nurse

vacation

honor 
English Word/Phrase

hool igan

hoover

horrific

humour

ice lollies

immunisation

inborn

inbuilt

jewel lery

jog memory (verb)

judgement

keen to put

label 1 ing

labour

lavatory

lawless little thugs

leapt

learnt

less keen on

local authority

1 iquidiser

\section{American Translation}

brat

vacuum cleaner

terrible

humor

popsicles

immun ization

innate

innate

jewe l ry

refresh memory

judgmen $\mathrm{t}$

excited about putting

label ing

labor

bathroom; toilet

juvenile delinquents

leaped

learned

uninterested in

public

blender 
English Word/Phrase

1011 ies

100

100 rolls

lustre

mark

mashed swede

master

meat pies

metal box

midwife

minder

minimising

moan (noun)

mongoloid

moulded

moved house

$\operatorname{muck}(y)$

muddled

mum

mushing

nappy

ne ighbour ( hood)

nightie
American Translation

suckers; popsicles

bathroom

toilet paper rolls

luster

grade

mashed turnip (or similar vegetable)

teacher

food similar to meat loaf

stroller

nurse; midwife

sitter

minimizing

complaint

person with Down's Syndrome

molded

moved to a new house

$\operatorname{mess}(y) ; \operatorname{dirt}(y)$

confused

mom; mother; mommy

mashing

diaper

ne i ghbor (hood)

pajamas 
English Word/Phrase

oestrogen

off-colour

ornaments

organise

overleaf

orthopaedic

packets

paediatric

paediatrician

paralise

parcel

parentcraft

patch (of time)

peppermint box

pincer grip

pin washing (verb)

play group

Play School

pluck up (verb)

plug hole

polythene

posting box

practise

\section{American Translation}

estrogen

sickly; out of sorts

knickknacks

organize

on the next page

orthopedic

packages; boxes

pediatric

pediatrician

paralyze

package

act of parenting

period (of time)

small box

holding thumb and forefinger together

hang laundry on clothes line

day care center; nursery school

Sesame Street

gather (verb)

drain

plastic

mailbox

practice 
English Word/Phrase

pram

programme

pub

pulling a flex

pullover

pushchair

pussy

put on people

put right

queing up

rather

realise

recognise

reel of cotton

ring (verb)

rip (verb)

rising twos

rising fives

round

rota system

rusks
American Translation

baby carriage; buggy

program

tavern; coffee shop

pulling on an electric cord

sweater

stroller

kitty; cat

ask for help from people

correct

lining up

somewhat

realize

recognize

spool of thread

circle (verb)

have an angry outburst; tantrum

children going on two years

children going on five years

around

rotating system

teething biscuits

sand box 
English Word/Phrase

sets alright in us

shan't

share out (verb)

shocked

shop bought

shunting

sick

sickening for something

sick up

silver sand

sling

slinging

sloshy

smack

smelt

snippets

sploshes

spongey

sticking

summarises

supplementary benefit

Syrup of Figs

\section{American Translation}

results in

don't

divide (verb)

traumatized

store-bought

pushing

vomit

becoming ill

throw up; vomit

children's play sand

baby backpack

throwing

messy

spank

smelled

phrases

splashes

spongy

pasting; gluing

summarizes

wel fare

laxative, such as Milk of Magnesia

understand; accept

supper 
English Word/Phrase

teats

teddy

tether (noun)

tick

tin

tinned food

tin on hinges

ti 11

to be to do...

top up (verb)

toxaemia

tranquilliser

travelling

trolley

trouser

turf her out

twigged

twitched

washing-up

washing-up bowl

washing-up 1 iquid

washing-up water

whilst

willy-nilly
American Translation

nipples

teddy bear

patience (noun)

check

can

canned food

can with hinged lid

until

to have to do ...

finish a feeding

toxemia

tranquilizer

traveling

shopping cart

pants; slacks

send her back to bed

noticed; learned; figured out

pulled

washing dishes

sink

1 iquid detergent

dishwater

while

haphazardly 
English Word/Phrase

wind (verb)

wool

worrying

yoghurt pot
American Translation

burp (verb)

yarn

troublesome

yogurt cup 


\section{APPENDIX C}

\section{TRI-COUNTY AGENCY LIST}

Albertina Kerr Center

$233-5247$

Associated Home Health Service

$233-5441$

Birthright

$221-0598$

Boys \& Girls Aid Society

$222-9661$

Brown Foundation

$248-6931$

Catholic Services for Children

$228-6531$

Center for Community Mental Health

289-1167

Childbirth Association

$245-3196$

Child Care Coordinating Council (4C)

$238-7007$

Citizens for Children

$222-2420$

Clackamas County Association for Retarded Citizens

$635-4318$

Clackamas County Health Division

$655-8471$

Contact Center Hotline

$231-4841$

Crippled Children's Division

$225-8095$

Cystic Fibrosis Foundation

$321-4015$

Easter Seals Society

$228-5108$

Foster Grandparents

$232-0463$

Foster Parents Association

$232-8383$

Harry's Mother

$238-4611$

Information \& Referral Services

Tri-County Community Council

$222-5555$ 
Interpersonal Training and Counseling Center

$761-4239$

Jewish Family and Child Service

$226-7079$

LaLeche

$282-9377$

Lamaze

$774-1140$

Lutheran Family Service

$228-7613$

Metropolitan Family Service

$228-7238$

Morrison Center

$232-1091$

Multnomah Association for Retarded Citizens

$223-7279$

Multnomah County Health Division

Parent-child Health

Satellite Prenatal Clins

Community Health Nursing

Family Planning

(S.E.) $248-5090$

(S.W.) 248-3431

$248-3649$

March of Dimes

$222-9434$

Naturopathic Medicine Clinic

$226-3717$

Neighborhood Options in Child Care **Serves Humboldt, Boise, Piedmont**

$289-5746$

Northwest Oregon Heal th Systems

297-2241

Oregon, State of

Albina Human REsources Center

$28.0-6931$

C.S.D. Region I

$238-8446$

Communicative Disorders Program

$229-5776$

Health Division

Maternal \& Infant Child Care Project

$229-5806$

**Serves Albina, Pen insula, St. Johns**

$280-6620$

O.S.U. Extension Services (Multnomah County)

$229-4830$

Outside IN

$223-4121$

Parent-child Services

$284-6267$

Parents Anonymous Northwest

$238-8818$

Planned Parenthood Association

$234-5411$

Portland Association for Childbirth Education (PACE)

$244-5429$ 
Portland Hotline

$252-0278$

Portland Public Schools

Citizen Information Center

Continuing Education for Girls

$233-8933$

Direction Services

$288-5361$

Regional Program for the Deaf

$288-5167$

288-5361,

ext. 38

Prepared Childbirth

$281-1815$

Red Cross

Preparation for Parenthood

$243-5200$

$243-5272$

Salvation Army--White Shield Home

$226-4053$

School-age Parents Program

$288-5173$

Southeast Women's Health Clinic

$234-9974$

U. S. Federal Information Center

$221-2222$

Visiting Nurses Association

$238-6767$

Volunteers of America--Family Center

$235-8655$

Washington County Association for Retarded

Citizens

$649-6110$

Washington County Public Health

$648-8881$

Waverly Children's Home

$234-7532$

Westover Community Medical Center

$243-2600$

Women, Infant, and Children Supplemental Food Program

$280-6615$

Women's Place Resource Center

$234-7044$

Women's Psychological Clinic (P.S.U.)

$229-4787$

Women's Resource Center (Y.W.C.A.)

223-6281,

ext. 67

Y.W.C.A. St. Johns Branch

$286-3797$ 
HOSPITALS

Bess Kaiser

$285-9321$

Dwyer Memorial

$659-6111$

Eastmoreland General

$234-0411$

Emanue 1

Public Information

$280-3200$

Family Planning

$280-4612$

Good Samaritan

Pubi ic Information

229-7205

Child Neurology Clinic

$229-7220$

Infant Hearing Resource

$229-7526$

Gresham Community

667-1122

Holladay Park

$233-4567$

Medical. Center

$226-6537$

Meridian Park (Tualatin)

$638-7654$

Oregon City

$656-0855$

Portland Adventist Medical Center

$257-2500$

Family Life Center

$257-2477$

Heal th Education

$257-2496$

Physicians and Surgeons

$224-6500$

Providence Medical Center

$234-8211$

Child Center

$234-9991$

St. Vincents

297-4411

Sunnyside Medical Center

$653-4411$

Tuality Community (Hillsboro)

$648-3161$

University of Oregon Health Sciences Center Abortion Clinic Hospital

Outpatient Clinics

Rosenfeld Center for Child Abuse

$225-8542$

$225-8811$

$225-8505$

$225-8194$

Willamette Falls (Oregon City)

$656-1631$

Woodland Park

$255-1313$ 